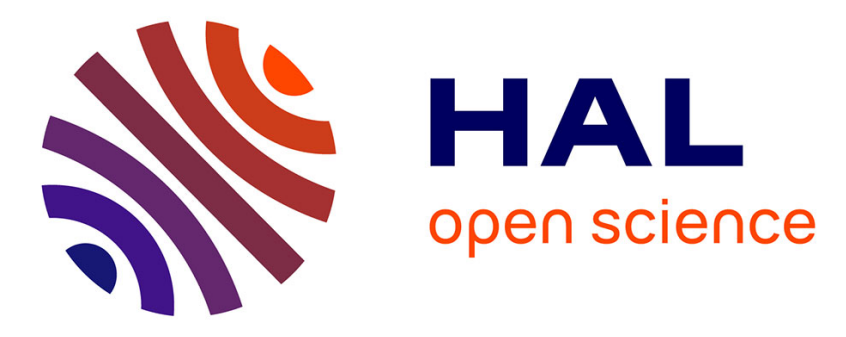

\title{
Mapping the crustal structure beneath the eastern Pyrenees
}

\author{
Jordi Diaz, Jaume J. Vergés, Sébastien Chevrot, Amanda Antonio-Vigil, \\ Mario Ruiz, Matthieu Sylvander, Josep Gallart
}

\section{- To cite this version:}

Jordi Diaz, Jaume J. Vergés, Sébastien Chevrot, Amanda Antonio-Vigil, Mario Ruiz, et al.. Mapping the crustal structure beneath the eastern Pyrenees. Tectonophysics, 2018, 744, pp.296-309. 10.1016/j.tecto.2018.07.011 . hal-02358173

\section{HAL Id: hal-02358173 \\ https://hal.science/hal-02358173}

Submitted on 11 Nov 2019

HAL is a multi-disciplinary open access archive for the deposit and dissemination of scientific research documents, whether they are published or not. The documents may come from teaching and research institutions in France or abroad, or from public or private research centers.
L'archive ouverte pluridisciplinaire HAL, est destinée au dépôt et à la diffusion de documents scientifiques de niveau recherche, publiés ou non, émanant des établissements d'enseignement et de recherche français ou étrangers, des laboratoires publics ou privés. 


\title{
Mapping the crustal structure beneath the eastern Pyrenees
}

\author{
Jordi Diaz ${ }^{\mathrm{a}, *}$, Jaume Vergés ${ }^{\mathrm{a}}$, Sebastien Chevrot ${ }^{\mathrm{b}}$, Amanda Antonio-Vigild ${ }^{\mathrm{d}}$, Mario Ruiz ${ }^{\mathrm{a}}$, Matthieu Sylvander ${ }^{\mathrm{c}}$, \\ Josep Gallart ${ }^{\mathrm{a}}$ \\ a Institute of Earth Sciences Jaume Almera ICTJA, CSIC, Barcelona, Spain \\ b Géosciences Environnement Toulouse, UMR 5563, Observatoire Midi Pyrénées, Université Paul Sabatier, 31400 Toulouse, France \\ ${ }^{\mathrm{c}}$ Institut d'Astrophysique et de Planétologie (IRAP), CNRS/UPS, Toulouse, France \\ ${ }^{\mathrm{d}}$ Departamento de Geología, Universidad de Oviedo, Spain
}

\section{A R T I C L E IN F O}

\section{Keywords:}

Crustal structure beneath eastern Pyrenees

Receiver function stacked sections

Local events modelling

Geological interpretation of the results

Eastward limit of the crustal imbrication

\begin{abstract}
A B S T R A C T
Two passive seismic profiles have been acquired in the eastern Pyrenees as part of the Pyrope and Orogen projects to investigate the crustal structure differences between this area and the central and western Pyrenees. Up to 28 broad-band stations were deployed along two orthogonal lines, with an interstation spacing close to $10 \mathrm{~km}$. High frequency receiver functions allowed us to obtain the main lithospheric interfaces along those lines. The NNE-SSW profile shows a well-defined Moho beneath Iberia, slightly deepening northwards. Beneath the Axial zone the Moho appears to be segmented but does not show evidence of crustal imbrication. Further North, the Moho appears again as a continuous interface located around $30 \mathrm{~km}$ depth. This image clearly differs from the conspicuous imbrication between the Iberian and Eurasian crusts observed westward. The E-W profile shows a smooth Moho thinning from a $40 \mathrm{~km}$ depth to the west of the profile to $23 \mathrm{~km}$ close to the coastline, evidencing the crustal thinning related to the Neogene extensional processes. Additional constraints on the geometry of the crust/mantle boundary in the Eastern Pyrenees are obtained from local moderate magnitude earthquakes recorded along the seismic lines during the experiment. In particular, a fan profile built from an event located near the Mediterranean coast suggests that crustal thickness differences between Iberian and Eurasian crusts can still be recognized $30 \mathrm{~km}$ westward of the Mediterranean coast, in an area that seems to mark the limit between regions dominated by compressive and extensive processes. We propose a model in which the observed dissimilar Moho structure beneath the Eastern Pyrenees is interpreted as the result of a different Mesozoic pre-shortening margin configuration. Seismic results are consistent with recently proposed tectonic models including an intermediate continental block separating Iberia and Europe by two basins with extremely thin crust or exhumed mantle.
\end{abstract}

\section{Introduction}

Starting in 2011 and following the TopoIberia-Iberarray and Pyrope broad-band deployments, a set of high density seismic profiles crossing the Pyrenees orthogonally to its main structural orientation have been acquired in a collaborative effort involving the Observatoire Midi-Pyrenees in Toulouse and the Institute of Earth Sciences Jaume Almera-CSIC in Barcelona (Fig. 1). These profiles have allowed us to explore seismically the global architecture of the orogen with unprecedented resolution. The presence of a crustal imbrication of the Iberian and European crusts beneath central and western Pyrenees, already documented by previous studies based on gravity data and active seismic profiles (see Section 3), has been imaged in detail by the western and central Pyrope profiles using receiver function (RF) stacked sections (Chevrot et al., 2015) and full-waveform tomographic inversions (Wang et al., 2016), providing relevant clues to the geodynamic evolution of the Pyrenean orogeny. Following the same approach, the eastern Pyrenees have been explored recently by means of two high-density profiles, oriented orthogonally. Previous studies have shown that this area shows a marked crustal thinning, with crustal thickness changing from 40 to $45 \mathrm{~km} 80 \mathrm{~km}$ to the west of the Mediterranean coastline to $<25 \mathrm{~km}$ offshore. However, the details of the transition between the central and eastern Pyrenees domains are still poorly understood, in particular regarding the location of the eastern limit of the crustal imbrication. The first profile, oriented NNE-SSW, extends from

\footnotetext{
* Corresponding author.

Email address: jdiaz@ictja.csic.es (J. Diaz)
} 


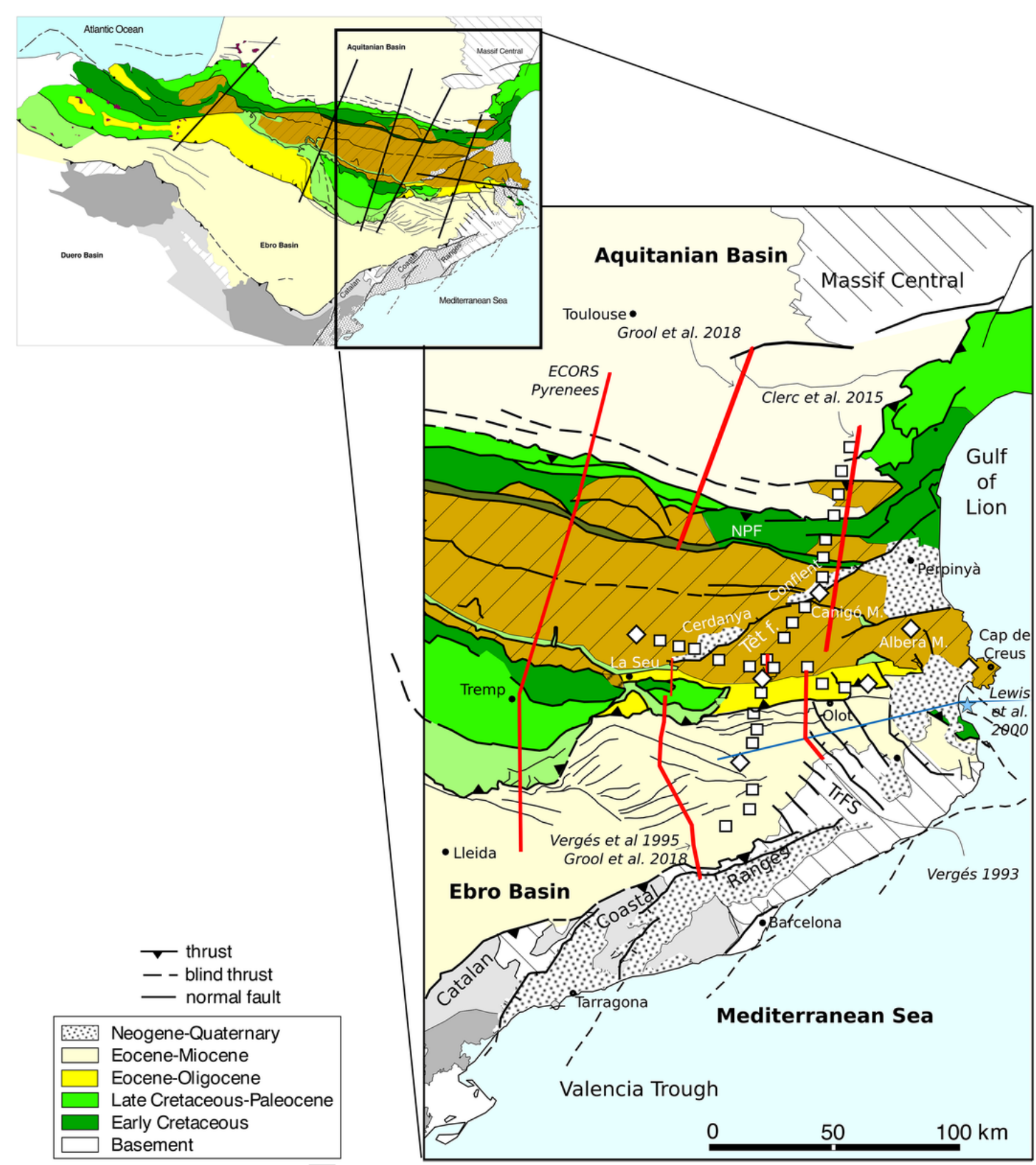

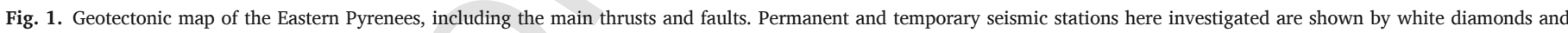

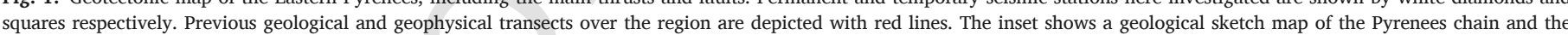

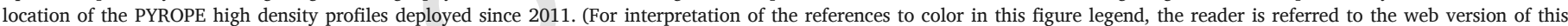
article.)

the Ebro Basin to the South to the limit of the Massif Central to the North and is oriented orthogonally to the main Pyrenean structures. The second profile has been designed to provide further details on the transition between the thickened crust in the central part of the Pyrenees and the thinned crust near the Gulf of Lion (Fig. 1).

In this contribution we investigate the structure of the crust beneath the eastern Pyrenees from the analysis of the natural seismicity data recorded along those profiles. We base our work on the calculation of the so-called P-wave receiver functions (RF), a widely used methodology allowing to infer first-order velocity discontinuities within the lithosphere and upper mantle (Vinnik, 1977; Langston, 1979). Additional information on the crustal structure beneath the zone of interest is derived from local events recorded along the profiles and interpreted using the wide-angle reflection/refraction modeling approach used in active source experiments. Although the data do not allow to derive a full velocity-depth model, the identification of PcP (reflection on the top of the lower crust) and PmP (reflection on the Moho discontinuity) phases offers additional constraints on the crustal geometry based on completely independent data and methodology.

The resulting crustal structure determined in our work has been combined with the existing geologic cross-sections to provide an integrated model of the Eastern Pyrenees built-up by Late Cretaceous-Early Miocene compression followed by crustal and lithospheric thinning during the opening of the Western Mediterranean.

\section{Tectonic setting}

The Pyrenean orogen built up by the closure and inversion tectonics of a deep basin, which developed during the transtensional-extensional motions between Iberia and Europe since the Early Jurassic. This long- 
term tectonic evolution, which is still controversial for some of the periods, produced the exhumation of large ribbons of lithospheric mantle along the entire length of the Pyrenean plate boundary from Albian-Cenomanian times, synchronously to the opening of the Bay of Biscay. There is a general agreement about the duration of the Pyrenean convergence from late Santonian to early Miocene. Present-day deformation is dominated by a scarce extension in the central and western Pyrenees, as shown by GPS and focal mechanisms results (Asensio et al., 2012; Chevrot et al., 2011; Nguyen et al., 2016) while some indications for compression have been reported in the eastern part of the chain (Rigo et al., 2015).

The partial north-dipping continental underthrusting of the Iberian lithosphere underneath European upper plate in the late Santonian stage shaped the Pyrenean fold belt as observed in the ECORS-Pyrenees deep seismic profile (Choukroune and ECORS Team, 1989; Muñoz, 1992; Roure et al., 1989). The Pyrenean orogen evolved as a roughly E-W-trending rectilinear and asymmetric doubly-vergent fold belt mostly detached above Upper Triassic evaporites and separated by a central antiformal stack of middle-upper crustal rocks with the most significant thrust system developed towards the south, on top of the Iberian lower plate (e.g., Puigdefàbregas and Souquet, 1986; Mattauer, 1990; Muñoz, 1992; Teixell, 1998; Capote et al., 2002; Vergés et al., 2002; among others). The Pyrenean orogen is about $450 \mathrm{~km}$ long and $80 \mathrm{~km}$ wide, although if one considers its continuation to the west towards the Cantabrian Mountains, its total length increases to reach $1000 \mathrm{~km}$.

From north to south the Pyrenean orogen includes (Fig. 1): a) the Aquitaine retro-foreland Basin, related to the northern Pyrenean wedge; b) the North Pyrenean Thrust System (NPTS), with a mean width of $30 \mathrm{~km}$ and north verging thrusts formed by Paleozoic, Mesozoic and Tertiary rocks.; c) the Axial Zone formed by an antiformal stack of mainly Paleozoic basement rock units and affected by intrusion of granites and granodiorites; d) the South Pyrenean Thrust System (SPTS), showing south oriented Alpine thrusts developed in the Mesozoic and Tertiary materials but also involving Paleozoic basement; and e) the Ebro Foreland Basin associated with the southern Pyrenean wedge (e.g., Muñoz, 1992; Vergés et al., 1995). The boundary between the Axial Zone and the North Pyrenean Thrust System is the North Pyrenean Fault (NPF), active since the Late Paleozoic Variscan cycle and interpreted as the trace of the Iberian-European plates boundary (Arthaud and Matte, 1975; Choukroune and Mattauer, 1978; Choukroune and ECORS Team, 1989). The E-W-trending Eastern Pyrenees interacted with the NE-SW-directed Catalan Coastal Ranges formed along the NW Iberian margin bounding the Ligurian-Tethys oceanic domains. The Catalan Coastal Ranges, involving basement blocks, resulted from the tectonic inversion of these basins mainly during the Middle Eocene stage (e.g., Guimerà, 1984; Anadón et al., 1985).

Crustal-scale models and estimates of N-S shortening for the Pyrenean orogeny are mainly derived from the study of the ECORS-Pyrenees Profile across the Central Pyrenees. Muñoz (1992) proposed $147 \mathrm{~km}$ of N-S shortening based on field geology and balanced and restored crustal sections. Using the same methods, Vergés et al. (1995) calculated $125 \mathrm{~km}$ through the Eastern Pyrenees and Teixell (1998) determined $75-80 \mathrm{~km}$ in the Western Pyrenees. New findings indicate that exhumed mantle separated Iberia from Europe during the Aptian-Cenomanian periods (e.g., Jammes et al., 2009; Lagabrielle et al., 2010). This hypothesis was integrated into a new series of geological cross-sections notably decreasing the amounts of previously calculated shortenings due to the new evaluations of the pre-shortening configuration of the Pyrenees margins and their crustal thicknesses (Jammes et al., 2014a, 2014b; Tugend et al., 2014; Ford et al., 2016; Grool et al., 2017; Mouthereau et al., 2014; Teixell et al., 2016).

The large number of geophysical data obtained along the profiles crossing the Pyrenees allows interpreting the structure of the north-dip- ping subducting Iberian crust beneath the European crust. The deepest crust is localized under the Central and Western Pyrenees, reaching depths over $40 \mathrm{~km}$ and showing an abrupt thinning approximately beneath the trace at surface of the NPF, passing from $45 \mathrm{~km}$ beneath the Axial zone to $28-30 \mathrm{~km}$ beneath the Aquitanian Basin. Before compression, the boundary between Iberia and Europe during the early Late Cretaceous times was located along the North Pyrenean strike-slip fault system that could be inherited from the Variscan orogeny (e.g., Arthaud and Matte, 1975; Choukroune and Mattauer, 1978; Olivet, 1996). The compressive structure of the easternmost Pyrenees initiated during the Late Cretaceous and possibly ended during the Oligocene-early Miocene (Vergés et al., 2002). This lack of time record for the end of compressive deformation is explained, in large part, because the present configuration of the NE Iberian Peninsula derives from the overprinting of the extensional opening of the Gulf of Lion and the Valencia Trough during the Neogene and Quaternary evolution of the Western Mediterranean (e.g., Lewis et al., 2000).

Two almost orthogonal systems of extensional faults intersect in the study area: a late Oligocene-middle Miocene NE-SW trending system that cuts the Catalan Coastal Ranges and a late Miocene to Present NNW-SSE directed system along the Transverse Ranges. These two fault systems produce a remarkable uplift along their common footwall, raising the Montseny Massif and the entire Eocene-Oligocene foreland basin defining a large wavelength syncline with a W- to WSW-plunge (Lewis et al., 2000). These transverse faults, from which the Amer-Brugent is the most important, are still active and characterized by a low magnitude but regular seismicity (Giménez et al., 1996).

Thin lithospheric mantle underlies onshore eastern Iberia at three main localities characterized by crustal and lithospheric thinning, high topography, and asthenospheric volcanism: in NE Iberia, on the southern flank of the Valencia Trough, and in SE Iberia (Vergés and Fernàndez, 2006). In NE Iberia thinning was more intense in the lithospheric mantle than in the crust, producing uplift and volcanism (Cabal and Fernàndez, 1995). The Olot alkaline basaltic volcanic province, in NE Iberia, is associated to the large Transverse fault system with radiometric ages that are progressively younger towards the W and WSW from 14 to 0.011 Ma (Martí et al., 1992; Saula et al., 1996; Bolós et al., 2015). The westward migration of both extension and volcanism into the NE corner of Iberia could be due to thinning of mantle lithosphere and coeval migration of a thermal anomaly starting at least during the late mid-Miocene times and still active (Lewis et al., 2000; Bolós et al., 2015). Although more difficult to quantify, the present-day configuration of the innermost part of the Pyrenees was also affected by the Neogene extensional system triggering uplift of large isolated massifs along the easternmost termination of the mountain chain (Canigó Massif at $2784 \mathrm{~m}$, Albera Massif at $1256 \mathrm{~m}$ and Cap de Creus at around $500 \mathrm{~m}$ of elevation). The presence of such elevations in this area where moderate crustal depths range between 30 and $25 \mathrm{~km}$ are documented suggests some degree of dynamic and/or thermal topographic support.

\section{Previous geophysical results}

One of the first and most relevant insights on the seismic structure of the Pyrenees resulted from the two E-W wide-angle reflection/refraction profiles acquired in the late 1970s throughout the northern and southern domains of the chain, providing the first velocity-depth models along the Pyrenees (Gallart et al., 1980; Daignières et al., 1981). Those results showed a crustal root beneath the central and western Pyrenees, with a significant thickness difference of the Iberian and Eurasian crusts. This root was later confirmed by vertical reflection profiles acquired during the ECORS experiment (ECORS-Pyrenees Team, 1988; Choukroune and ECORS Team., 1989) and by studies using receiver functions from teleseismic data recorded at permanent and temporal broad-band stations deployed across the Pyrenees (Díaz et al., 
2012; Chevrot et al., 2015; Mancilla and Diaz, 2015). In addition, results based on RFs suggest that near the western termination of the Pyrenees, the Iberian and Eurasian Mohos overlap for few tens of kilometers (Diaz et al., 2012). The full-waveform inversion of data recorded along a profile crossing the western Pyrenees (Wang et al., 2016) has recently evidenced the presence of mantle intrusions reaching the uppermost part of the crust in the western Pyrenees.

Since the early contributions of Gallart et al. (1980) and Daignières et al. (1981) it has been shown that an important crustal thinning does occur beneath the Eastern termination of the chain. Fan profiles across the chain recorded during the same pioneering experiment (Hirn et al., 1980) evidenced the significant difference in Moho depths across the eastern termination of the Pyrenees. Later on, Gallart et al. (2001) used onshore/offshore seismic profiles to investigate the deep crustal features at the transition from the Pyrenean range to the Gulf of Lion. The results show that this area is marked by a continued crustal thinning seaward that starts onshore. The authors concluded that the Neogene extensional tectonics associated to the opening of the Provençal basin and the anti-clockwise rotation of the Corsica-Sardinia block (Gueguen et al., 1998) together with the Upper Miocene-Recent active extension (Lewis et al., 2000) dominates the transition from the Pyrenean domain of NE Iberian Peninsula to the adjacent Mediterranean margin. Mancilla and Diaz (2015) obtained a crustal depth map of the westernmost Mediterranean region from the estimation of crustal thickness beneath the stations of the TopoIberia-Iberarray experiment. Diaz et al. (2016) integrated those results with Moho depths estimations from deep seismic sounding profiles to build an integrated crustal thickness map with a lateral resolution around $60 \mathrm{~km}$, showing a step thinning of the crust between $1.8^{\circ} \mathrm{E}$ and $2.4^{\circ} \mathrm{E}$ followed by a more gradual thinning till the coastline. Dashed red line in Fig. 2 shows the $35 \mathrm{~km}$ Moho depth isoline in this map, illustrating the area affected by significant crustal thickening. A recent S-wave tomography model (Palomeras et al., 2017) confirms the Moho depth variation underneath the Eastern Pyrenees. P-wave tomography (Chevrot et al., 2014) consistently shows low seismic velocities at lithospheric levels $(50-150 \mathrm{~km})$ beneath the thinned crust area in NE Iberia east of the Têt fault.

The earthquake distribution in the eastern Pyrenees-NE Iberia area (Fig. 2b) shows a different pattern north and south of the axial zone. In the southern side, the seismicity is located in a rather continuous band reaching $2.5^{\circ} \mathrm{E}$. Further east, the seismicity is scarce and concentrated in a couple of small patches in the Empordà Basin and the Gulf of Roses. A more important cluster is located further South, in the area where the Transverse Ranges and the Catalan Coastal Ranges intersect.
In the northern side of the Pyrenees, seismicity is scarce west of $1.5^{\circ} \mathrm{E}$ and increases eastward along a zone located between $42.6^{\circ} \mathrm{N}$ and $43^{\circ} \mathrm{N}$ extending till the Gulf of Lion.

Bouguer anomaly maps (e.g. Ayala et al., 2016) show a negative anomaly reaching $-200 \mathrm{mGals}$ beneath the Axial Zone at longitudes of $1.5^{\circ} \mathrm{e}$ to $2^{\circ} \mathrm{E}$. Further East, Bouguer anomaly increases to reach values of $50-70 \mathrm{mGals}$ near the shoreline (Fig. 2c). It is worthy to note that the large positive anomalies identified in the western and central part of the Pyrenees (Mauléon, Saint-Gaudens, Lourdes) are not observed in the eastern zone. Gravity data was first studied by Casas et al. (1997), already stating that the easternmost Pyrenees have a crustal structure clearly different from its central sector. Rivero et al. (2002) derived a crustal thickness map of the eastern Pyrenees from gravity data using empirical relationships and spectral analysis. This map shows a nearly monotone decrease of the Moho depth, from $44 \mathrm{~km}$ in Andorra to 23 in the Cap de Creus. Later on, Gunnell et al. (2008) analyzed gravity data altogether with geoid anomalies, topography and heat flow to derive a similar map. More recently, Torne et al. (2015) obtained a crustal thickness map at the scale of the Iberian Peninsula from the joint inversion of geoid and elevation, also depicting the crustal thinning in the Eastern Pyrenees.

\section{Data acquisition and processing}

\subsection{Receiver function data}

The objective of the RF methodology is to isolate the P-S conversions generated at first order velocity discontinuities located beneath the station by deconvolving the vertical component from the horizontal components in the time window including the first $\mathrm{P}$ arrival of teleseismic events and its coda. It is assumed that vertical component deconvolution removes the signature of the source time function and the possible source-side and deep-earth propagation effects. Although this hypothesis is only true in the case of a laterally homogenous and isotropic media, it has been proved that RF can also be useful to investigate the crustal structure in zones with dipping layers and/or anisotropy (Lombardi et al., 2008).

The Eastern Pyrenees PYROPE deployment involved 28 broad-band stations spaced by $7-10 \mathrm{~km}$ and acquiring data during a 15 months period (4/2015-6/2016). Data from permanent stations from the IGN (Instituto Geográfico Nacional, 1999), ICGC (Institut Cartogràfic i Geològic de Catalunya, 2000) and RESIF (RESIF, 1995) networks at convenient locations have been gathered to complete the profiles. For a)

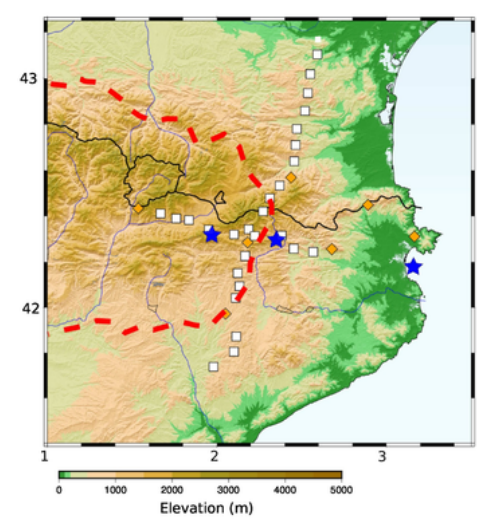

b)

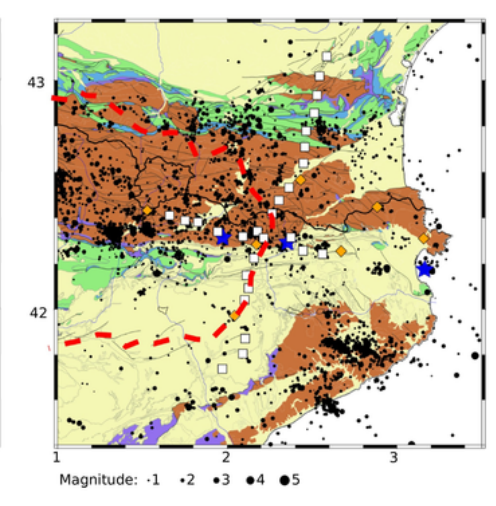

c)

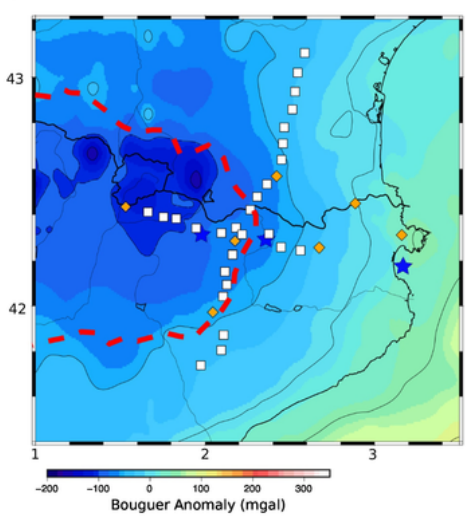

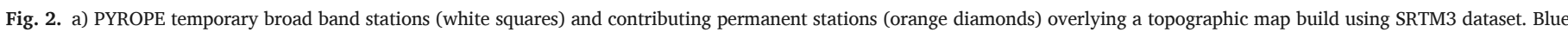

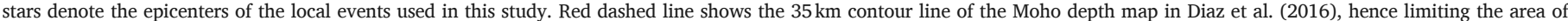

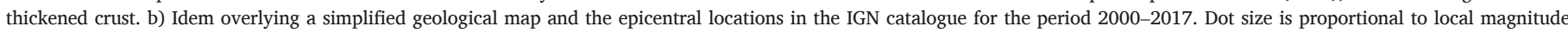

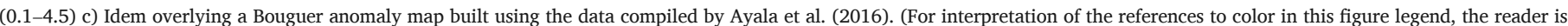
referred to the web version of this article.) 
these stations, 2 complete years of data have been analyzed (2015-2016). The NNE-SSW profile was recorded by 18 portable stations and 3 permanent sites. The remaining 10 stations were deployed along the E-W profile, extended eastwards by three permanents stations (Figs. 1 and 2). The first step in data processing was to select teleseismic events with magnitude higher than 5.5, epicentral distances between $35^{\circ}$ and $95^{\circ}$ and clear P arrivals. We then calculated the corresponding RF by frequency domain deconvolution (Langston, 1979) of the vertical component from the horizontal components in the time window corresponding to the $\mathrm{P}$ arrival and its coda. The deconvolution was performed using the classical "pwaveqn" software (Ammon, 1997). As we are interested in the crustal convertors, we use a high value of the low-pass gaussian filter parameters to preserve the high frequency content of the signals and hence allow a better delineation of the crustal discontinuities. After several trials, we selected a value of 10 for this parameter, equivalent to pulse width around $0.5 \mathrm{~s}$ and cut-off frequency around $5 \mathrm{~Hz}$. A standard value of 0.05 is used as water level parameter to avoid numerical problems during deconvolution. An automatic workflow has been implemented to calculate RFs, retaining only those signals with large signal-to-noise ratio. In a second step, the selected events have been visually inspected in order to discard unclear records. The number of retained events ranges between 15 and 30 for the temporary stations and reaches a mean value close to 50 for the permanent stations included in the profiles. In order to provide a better depth resolution in the crustal structures and to get insights on possible intracrustal converters, we have tested if the application of high-pass filters to the data prior to deconvolution provides or not satisfactory results. This approach appears to be effective but requires to discard events with dominant low frequency content. After testing different values, a high-pass filter with a corner frequency of $1 \mathrm{~Hz}$ has been used to calculate the RFs used to construct the stacks.

The depth to the Moho discontinuity has been first analyzed using the H-א method (Chevrot and Van Der Hilst, 2000; Zhu and Kanamori, 2000) (Fig. 3). This approach, widely used nowadays, considers a mean crustal velocity and estimates the arrival time of the Ps, PpPs and PsPs phases for each given combination of $\mathrm{H}$ and $\kappa(\mathrm{Vp} / \mathrm{Vs})$. The amplitude of the real RFs at those times is then evaluated in the $(H, \kappa)$ parameter space, and the presence of a well-defined maximum in the stacking surface defines the preferred solution for each station. In cases of weak Moho conversion or low energy of the multiples, this method can produce undefined results. To check their consistency, the crustal depth has also been estimated by picking the P-to-S arrival time in the summation trace obtained after applying a Ps-moveout correction to the reference ray parameter of $0.065 \mathrm{~s} / \mathrm{km}$ and converting to depth using the average $\mathrm{Vp} / \mathrm{Vs}$ ratio from the application of $\mathrm{H}-\mathrm{\kappa}$ stacking method to the rest of the stations and a mean crustal velocity fixed at $6.3 \mathrm{~km} / \mathrm{s}$. It has been shown that variations of $\pm 0.1 \mathrm{~km} / \mathrm{s}$ in Vp result in changes of $\pm 0.6 \mathrm{~km}$ in the Moho depth, making the choice of the reference Vp value not a critical issue (Mohsen et al., 2005; Nair et al., 2006). Table 1 summarizes the results derived from this approach.

In a second approach, the RFs are stacked using a simple form of migration (Jones and Phinney, 1998) to obtain images of the lithosphere in depth domain (Figs. 4 and 5). RFs are traced back along their raypaths using a $1 \mathrm{D}$ velocity model, the amplitudes contributing to each cell of the model are stacked and the data is projected along a profile. Therefore, the amplitude contrasts in the final images depict

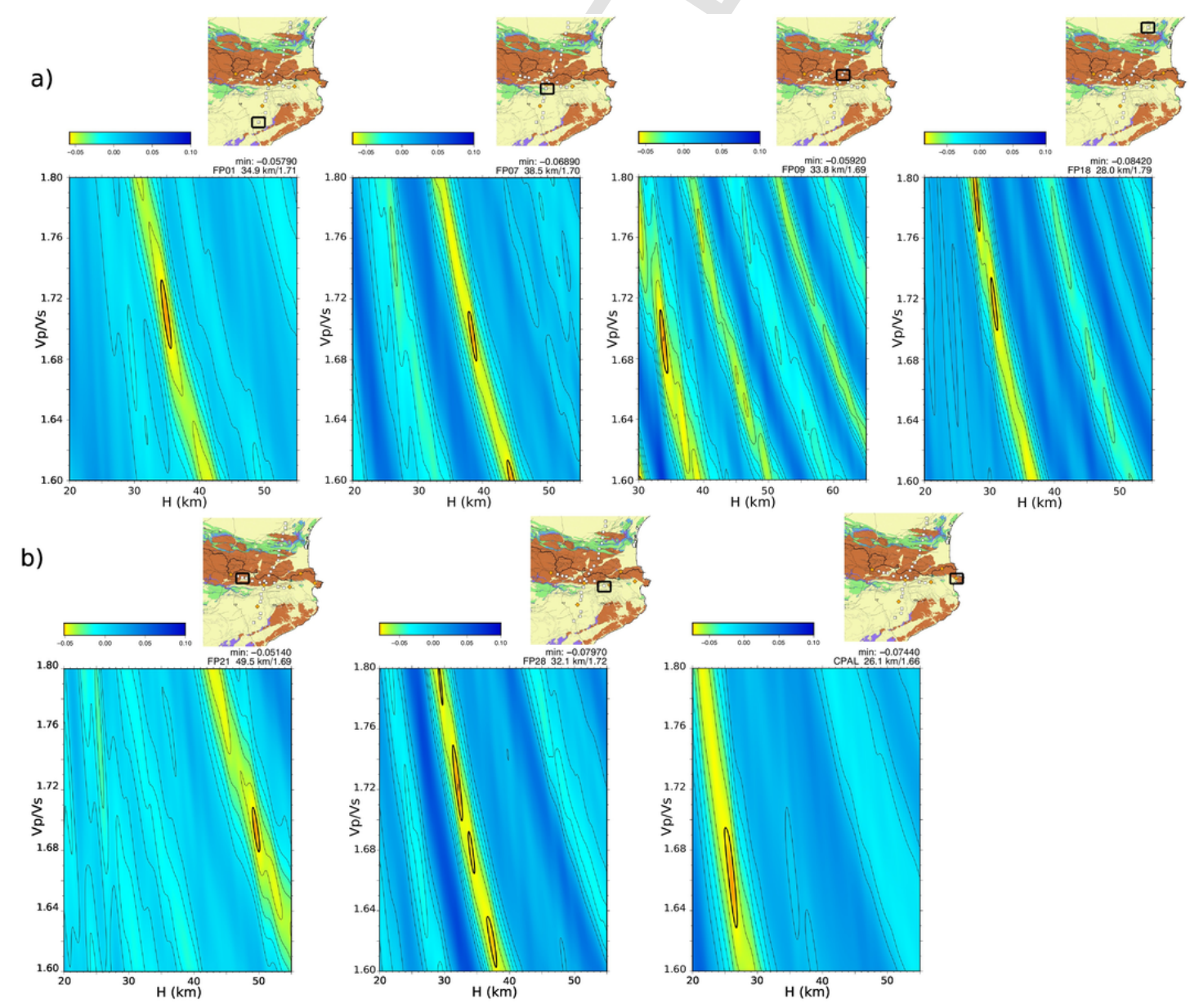

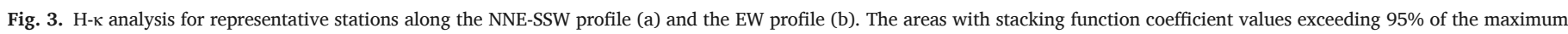
are marked using bold ellipses. The geographical location of each site is shown in the corresponding map inset. 
Table 1

Crustal parameter estimations using the H-к approach. Columns are for: Station name, latitude, longitude, elevation, number of retained RFs, crustal thickness (km) and Vp/Vs.

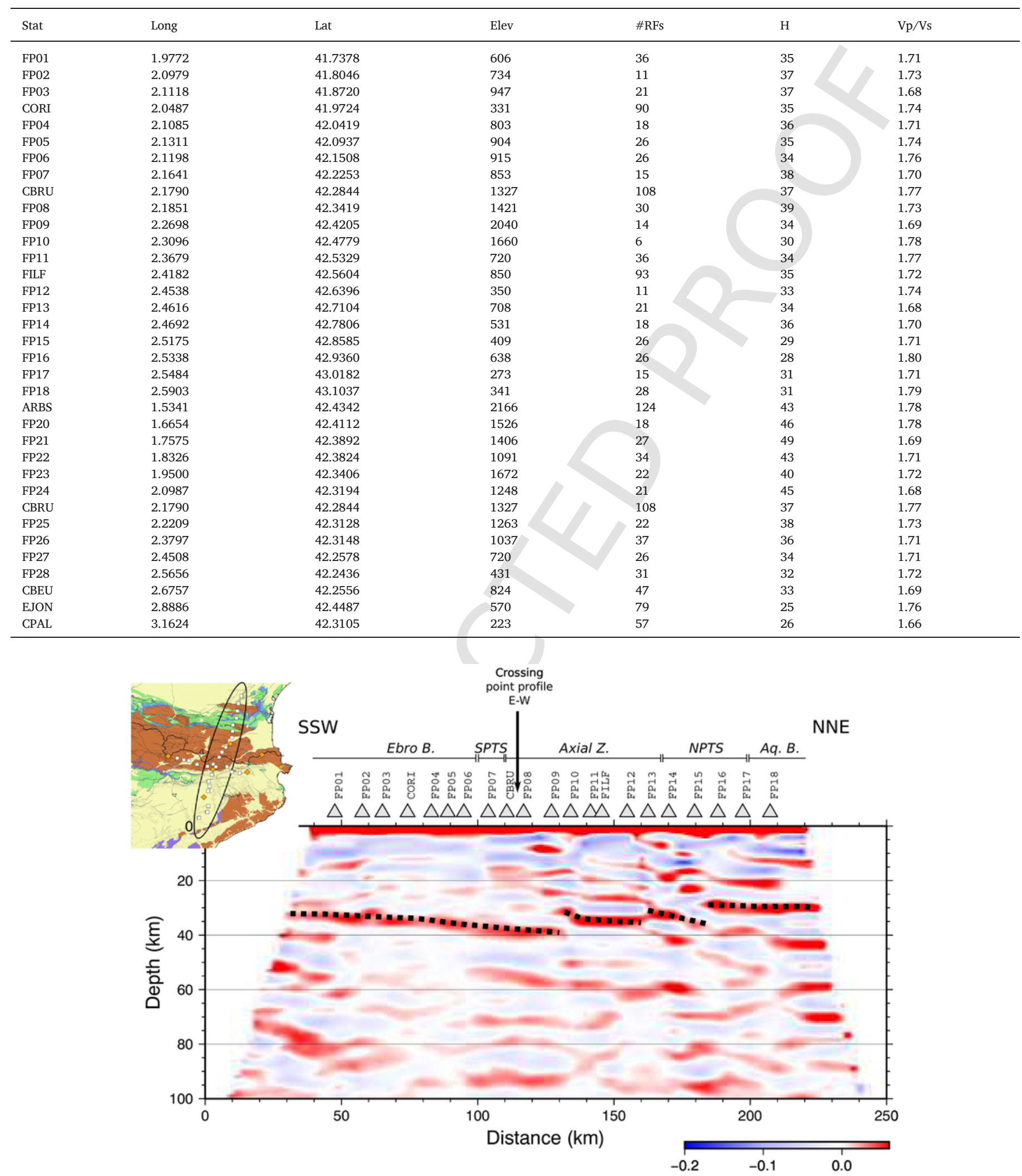

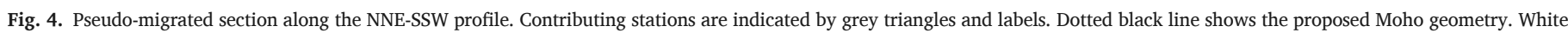
circles mark the crustal depths derived from the Н-к analysis. 


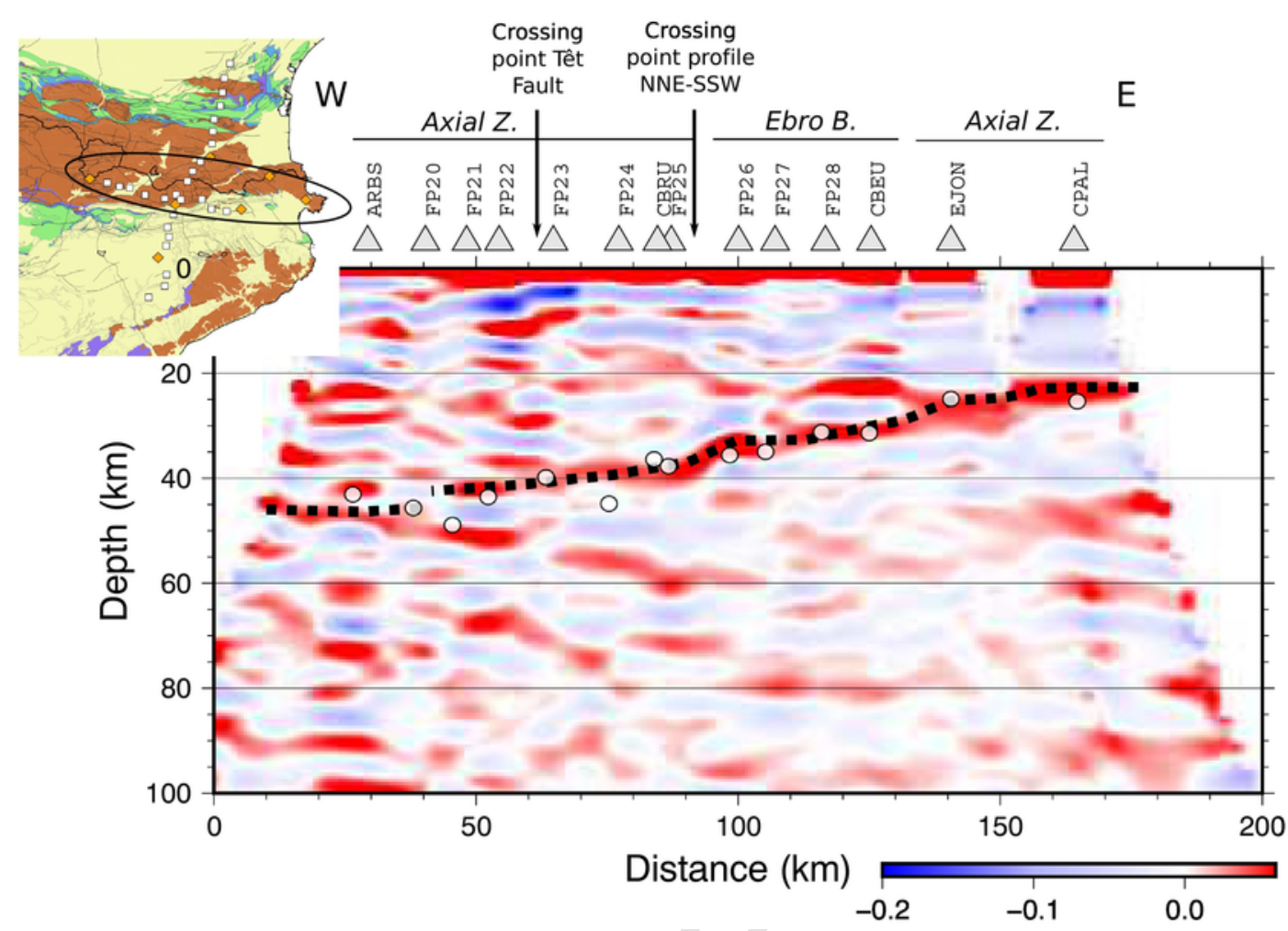

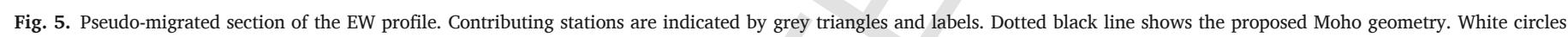
mark the crustal depth derived from the H-к analysis.

the zones where incoming waves suffer P-to-S conversions. In the pseudo-migrated sections red colors represent conversions on interfaces with an increase of seismic velocity with depth (e.g. Moho). Accordingly, blue colors are for conversions generated at interfaces above low velocity zones. Applying a high-pass filter to the data prior to deconvolution allows us to obtain thinner pulse widths and hence better delineated crustal interfaces. On the other hand, excessively high-pass filtered data results in inconsistent and patchy images which do not provide useful information. The vertical resolution of the RFs is controlled by the wavelength of the P-to-S converted phase, which depends on the spectral content of the recorded signal and propagation velocity (e.g. Sheriff and Geldart, 1982). As the RFs have been calculated at frequencies above $1 \mathrm{~Hz}$, assuming a typical S-wave velocity close to $3.5 \mathrm{~km} / \mathrm{s}$ means that the vertical resolution will not be better than $3-4 \mathrm{~km}$. We have checked the effect of the velocity model in the building of the stacked section by calculating the same section using the ak135 model for continental structure (Kennett et al., 1995), including a 2-layered, $35 \mathrm{~km}$ thick crust. The aspect of the image is very similar, although the convertors appear $2-3 \mathrm{~km}$ deeper. This variation is smaller than the estimated resolution of our data and hence we must conclude that the use of different realistic crustal velocity models do not affect the interpretation of the results. The interpretation of these sections will be discussed in Section 6.

\subsection{Record sections obtained from local events}

During the recording time of the PYROPE profiles, three events with local magnitudes ranging between 2.5 and 4.3 were located in the zone (Fig. 2a). The largest one had its epicenter in the Gulf of Roses, close to the eastern end of our E-W profile. The other two were located in the central part of the East-West profile, close to its intersection with the NNE-SSW profile. The occurrence of these events during the deployment of the stations has provided a unique opportunity to process the data following the approach typically used in controlled source wide-angle reflection/refraction experiments in order to get information on the velocity/depth structure in the zone.

In a first step, the events have been relocated by manually picking arrival times both in the profiles stations and in the neighbor permanent ones. The best results were achieved using Hypo71 to invert the arrival times of $\mathrm{P}$ and $\mathrm{S}$ phases using only the closest stations. Final locations and origin times are in good agreement with the catalogue provided by the different agencies, with differences below $1.8 \mathrm{~km}$. (Table 2). In a second step, the signals from each event were extracted from our database and the traces arranged to build record sections with a reduction velocity of $6 \mathrm{~km} / \mathrm{s}$. Following the classical procedure, the arrival times on those record sections were picked and identified as Pg, PcP and PmP phases in order to obtain a velocity/depth model using Rayinvr (Zelt and Smith, 1992), a classical ray-path based modeling method.

The NNE-SSW profile has a length of $180 \mathrm{~km}$ and is imaged using waves from events $\mathrm{C} 1$ and $\mathrm{C} 2$, both located in its central sector. These two events are not fully aligned along the profile but lay $17 \mathrm{~km}$ west and $12 \mathrm{~km}$ east respectively. Event C2 shows direct waves at offsets up to $100 \mathrm{~km}$, both in the south and north directions (Fig. 6a). These phases, interpreted as being refracted within the basement and labeled Pg, propagate with apparent velocities of $5.5-6.0 \mathrm{~km} / \mathrm{s}$ and $6.0 \mathrm{~km} / \mathrm{s}$ to the south and north respectively. A weak secondary phase arriving later has been identified at offsets of $55-90 \mathrm{~km}$ to the north. This phase can be interpreted as the wide-angle reflection at the top of the lower crust (PcP) or, alternatively, as a reflection at the base of the crust (PmP). Event C1 (Supplementary Fig. S1) provide similar features, with PcP/PmP arrivals in the 75-90 km range to the north (Fig. 6a) which are not observed along the southern sector of the profile.

The EW profile, approximately $150 \mathrm{~km}$ long, has been sampled by waves from the three investigated events, which are almost exactly aligned with the profile. Events C1 and C2 are located near the center of the profile, while event C3 lies at the western end of the line, allowing to record signals at large offsets sampling the base of the crust. The 
Table 2

Hypocentral determinations form the ICGC and IGN agencies and relocations using portable instruments.

\begin{tabular}{|c|c|c|c|c|c|c|c|}
\hline Н-к Id. & Date & Time & Lat & Lon & Depth & Mag & Agency \\
\hline $\mathrm{C} 1$ & $18 / 11 / 15$ & 11:10:01 & 42.3274 & 1.9623 & 2 & 3.2 & IGN \\
\hline C1 & $18 / 11 / 15$ & 11:10:00.6 & 42.33 & 1.95 & 6 & 3.0 & ICGC \\
\hline $\mathrm{C} 1$ & $18 / 11 / 15$ & 11:10:00.6 & 42.3213 & 1.9533 & 4.1 & & \\
\hline $\mathrm{C} 2$ & $20 / 07 / 15$ & $11: 06: 05$ & 42.3024 & 2.3712 & 4 & 2.6 & IGN \\
\hline $\mathrm{C} 2$ & $20 / 07 / 15$ & $11: 06: 05.4$ & 42.30 & 2.37 & 5 & 2.5 & ICGC \\
\hline $\mathrm{C} 2$ & $20 / 07 / 15$ & $11: 06: 05.5$ & 42.2955 & 2.3750 & 2.2 & & \\
\hline C3 & $29 / 10 / 15$ & $00: 37: 47$ & 42.1954 & 3.1942 & 10 & 4.0 & IGN \\
\hline C3 & $29 / 10 / 15$ & $00: 37: 47.6$ & 42.18 & 3.16 & 10 & 4.3 & ICGC \\
\hline C3 & $29 / 10 / 15$ & $00: 37: 47.6$ & 42.1798 & 3.1643 & 6.1 & & \\
\hline
\end{tabular}

record section built from event C1 (Supplementary Fig. S2) allows us to identify the Pg phase at offsets up to $60 \mathrm{~km}$, both in the W and E sectors, with apparent velocity close to $6 \mathrm{~km} / \mathrm{s}$. To the East, a second arrival can be identified in the $50-100 \mathrm{~km}$ offset range and has been tentatively identified as a PcP. Event C2, with lower magnitude, only allows us to identify Pg arrivals at shorter distances (Supplementary Fig. S2). The record section built from event C3 provides evidences of three distinct phase arrivals (Fig. 6b). Pg waves with apparent velocity close to $6 \mathrm{~km} / \mathrm{s}$ are identified at ranges $-10 /-80 \mathrm{~km}$. Later on, a second arrival with higher apparent velocity is identified between -90 and $-140 \mathrm{~km}$ and interpreted as a PcP phase. Finally, a high energetic later phase has been identified between -60 and $-140 \mathrm{~km}$, interpreted as a wide-angle reflection at the base of the crust, PmP.

The records along the NNE-SSW profile of the magnitude 4.3 event labeled C3 and located in the Mediterranean coast allowed us to construct a fan profile sampling the crust structure eastwards of the profile (Fig. 6c). Most of the stations (FP05-FP13) with clear arrivals are located at distances ranging between 86 and $74 \mathrm{~km}$ and backazimuths between $\mathrm{N} 260^{\circ} \mathrm{E}$ and $\mathrm{N} 320^{\circ} \mathrm{E}\left(\mathrm{N} 100^{\circ} \mathrm{W}, \mathrm{N} 40^{\circ} \mathrm{W}\right)$. As discussed later, the phases show large differences in their arrival times which results from complex Moho geometry.

\section{Interpretation of the results}

\subsection{RFs migrated profiles}

a) NNE-SSW profile

The results from the H-k method show a clear Moho in the southern segment of the profile, with a depth close to $35 \mathrm{~km}$ at station FP01 and gently dipping north reaching a depth of $38 \mathrm{~km}$ beneath station FP07 (Fig. 3a). To the north of this station, the central segment of the profile, sampling the Axial Zone and the NPTS, the results are less clear, as H-K stacking does not show clear correlation maximum to be attributed to the Moho conversion (see FP09 in Fig. 3a). North of the NPTS (station FP18 in Fig. 3b), the H-א are again well defined, showing a subhorizontal Moho, with a depth close to $28 \mathrm{~km}$.

The stacked record section along this profile (Fig. 4) shows a Moho differentiated in up to 4 segments. For most of the stations, the crustal depth estimations arising from the $\mathrm{H}-\mathrm{\kappa}$ analysis (white circles in Fig. 4) agree nicely with the stacked record section, with differences within the estimated vertical resolution. The southern edge of the RF stacked section shows a well-defined Moho located at $35 \mathrm{~km}$ depth and gently dipping to the north to reach $37 \mathrm{~km}$ beneath station FP07. The central segment of the transect corresponds at surface to the southern-vergent Axial Zone and the NPTS and shows a higher degree of complexity. The Moho appears here as a segmented reflector; beneath stations CBRU and FP08, the Moho is identified at around $40 \mathrm{~km}$ depth, following the gentle north-dipping observed beneath the southern sector. Further north, the pseudo-migrated image built using high frequency RFs sug- gests that the Moho is formed by two different segments gently dipping north (stations FP09-FP12 and FP13-FP15 in Fig. 4). These segments, separated by sharp steps, stand 5-7 km higher than the adjacent segment to the south and are interpreted as smaller continental blocks located between the Iberian and Eurasian plates. As we are using high frequency RFs, we need to confirm that the segmented image of the Moho beneath the Axial Zone do not result from spurious effects of small-scale lateral variations in the shallower velocity structure. In order to do so, we have recalculated RFs using a more conventional $2 \mathrm{~Hz}$ Gaussian filter, as used previously for other PYROPE profiles (Chevrot et al., 2018). The corresponding NNE-SSW stacked profile (Supplementary Fig. S3) provides a more blurred image, but the presence of a couple of discontinuous Moho segments is still clearly visible. Several convertors are identified within the uppermost $20 \mathrm{~km}$ of crust. Their interpretation is problematical due to the lack of consistency between neighboring stations and the possible contribution of reverberations. The northern segment of the profile, from FP15 to FP18, shows the base of the European crust as a subhorizontal convertor located at $30 \mathrm{~km}$ depth, although both the H-K method and the stacked section suggest that its southern end (station FP15) is slightly more superficial. Above and subparallel to the European Moho there is a consistent convertor at about $20 \mathrm{~km}$ depth that, according to previous models from active source seismic profiles, can be interpreted as the top boundary of the lower crust.

Therefore, this transect across the eastern Pyrenees is clearly different from those across the western and central Pyrenees presented in Chevrot et al. (2015), where the Iberian crust appears to be imbricated with the Eurasian one and only two Moho can be differentiated. The Iberian segment on those sections shows a typical lower plate geometry reaching depths of $50-55 \mathrm{~km}$ and developing the most important flexural foreland basin. Above it, the position and subhorizontal dip of the European Moho displays an upper plate position. The new results in the eastern Pyrenees show a different Moho configuration, with 4 different segments and no indications of a large flexure of the Iberian crust.

\section{b) E-W profile}

The E-W profile is obliquely crossing the main compressive tectonic units in the southern Pyrenees. The profile is located on the Axial Zone basement from its western end (permanent station ARBS) to station FP26, located near the contact between the Axial Zone and the Cadí thrust sheet (Vergés, 1993; Vergés et al., 1995). From FP26 to permanent station CBEU, the profile is subparallel to the Cadí thrust sheet carrying early-middle Eocene foreland basin sequences above the Vallfogona thrust that is cropping out, together with the Albanyà Fault, near the permanent station CBEU. From this station to the east, the profile crosses the Neogene Empordà Basin masking the SW-vergent Figueres-Montgrí thrust sheets overprinted by the NW-SE trending sets 

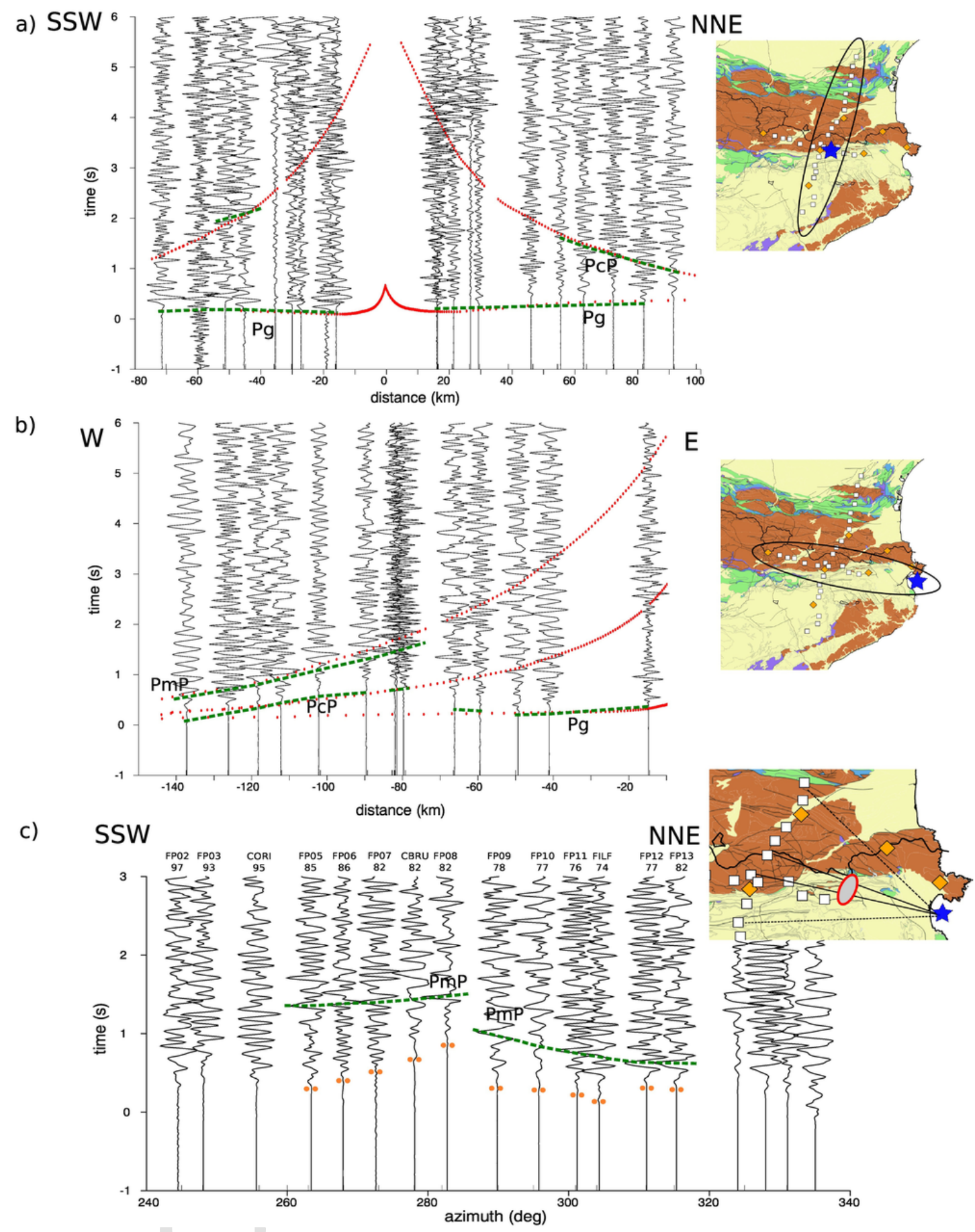

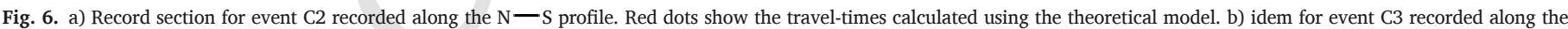

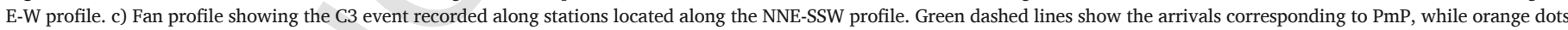

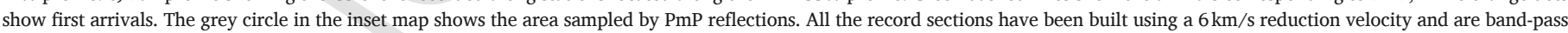

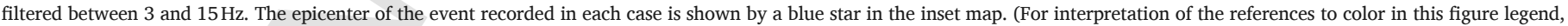
the reader is referred to the web version of this article.)

of Neogene normal faults (Fig. 1) (Lewis et al., 2000; Pujadas et al., 1989).

The H-א examples along this profile, shown at Fig. 3b, show a great variability of the Moho depth. To the West, station FP21 shows a thick crust, with a well-defined Moho located close to $50 \mathrm{~km}$. Moving East, station FP28 shows again a clear Moho, but with a depth close to $32 \mathrm{~km}$, hence evidencing a significant crustal thinning. Results for the permanent stations at the eastern edge of the profile (EJON and CPAL) confirm this eastward thinning, with Moho depths located at only $26 \mathrm{~km}$ near the Mediterranean coast.

The corresponding RF stacking image (Fig. 5) allows a continuous visualization of this lateral variation in crustal thickness. As in the previous case, there is a good agreement between the crustal depth estimations from the H- $\mathrm{\kappa}$ analysis and the stacked section. The western termination of this transect, sampled by the ARBS permanent station, shows a rather complex image, with multiple positive convertors at crustal levels. Although the identification of the conversions is unclear, 
for consistency with the results compiled in Diaz et al. (2016) and those obtained along the eastern profile in Chevrot et al. (2015), we favor the interpretation relating the Iberian Moho to the deeper of the observed convertors, located at $43 \mathrm{~km}$ depth.

Further East, the image beneath sites FP20-FP23, is still rather complex, as two convertors located around $30-35 \mathrm{~km}$ and $40-45 \mathrm{~km}$ depth can be related to the Moho. However, we favor a model with a Moho located around $40 \mathrm{~km}$ depth, as it provides a better continuity along the profile and is more consistent with previous models (Diaz et al., 2016). At upper crustal levels, roughly between 5 and $10 \mathrm{~km}$ depth, a strong negative convertor is imaged beneath sites FP22 and FP23, with a offset of a couple of kilometers between them. These two sites are located on each side of the Têt fault, that delimits the eastern boundary of the Cerdanya basin. As in the case of the NS transect, this feature can be interpreted as evidence for a low seismic velocity zone that might be associated to the Têt fault, although, as in the previous case, denser acquisition will be needed to settle this point. Below this feature, a positive convertor can be followed east and west of FP23 at different depths (12 vs. $8-10 \mathrm{~km}$ ). Models derived from the analysis of wide-angle reflection/refraction models (Gallart et al., 1980) have shown a velocity change at this level, interpreted as the bottom of the crystalline basement. Therefore, the high frequency RFs suggest that a change in the basement depth does occur beneath the approximate trace of the Têt fault beneath the Axial Zone of the Pyrenees.

To the East of station FP23, the transect has a clearly different character. The Moho discontinuity shows a rather smooth crustal thinning, with a depth varying from around $40 \mathrm{~km}$ beneath station CBRU to values slightly above $20 \mathrm{~km}$ beneath the Mediterranean coastline. Two prominent convertors can be observed at station CBEU, the upper one located at $22 \mathrm{~km}$ depth and the lower one, interpreted as the Moho, located around $30 \mathrm{~km}$ depth. Station EJON seems to show a complex Moho, but this could be related to out-of-line effects when projecting the results of this station, located some tens of $\mathrm{km}$ northward of the main profile (see Fig. 1). Within the crust, a convertor deepening to the east can be identified rather consistently, going from $18 \mathrm{~km}$ beneath FP24, to $20 \mathrm{~km}$ beneath stations CBRU and FP25, $25 \mathrm{~km}$ beneath stations FP26 and FP27 and connecting with the strong conversor at $22 \mathrm{~km}$ beneath CBEU. Although the image has to be taken with caution, it can be interpreted as evidencing a strong thinning of the lower crust, that would hence accommodate a large part of the total crustal thinning.

\subsection{Wide angle reflection/refraction profiles}

Active seismic profiles are typically interpreted using forward modeling or inversion approaches allowing to infer a velocity-depth model accounting for the phase arrivals observed at all the available shots records (record sections). Usual experiments using controlled sources are designed to obtain record sections with optimized data density and distance range. The approach here presented, using natural seismic events, does not allow us to infer detailed velocity-depth models. However, the interpretation of natural seismicity data in terms of wide-angle reflection/refraction profiles is still useful, as it provides an independent criterion to validate or not the large-scale features derived from the RFs profiles.

\section{- NNE-SSW profile}

As described in Section 3.2, two phases have been identified in the NNE-SSW record section, tentatively ascribed to a refracted wave within the basement $(\mathrm{Pg})$ and to a reflected wave at the top of the lower crust (PcP) or at the base of the crust (PmP). In order to model those phases, the proposed velocity-depth model (Fig. 7a) includes two discontinuities, one at mid-crust level and the second one corresponding to the Moho and fixed to fit the regional Moho depth maps (Diaz et al., 2016; Mancilla and Diaz, 2015). The velocity in the upper part of the crust is controlled by the Pg arrivals and has been modeled by a gradient from $5.7 \mathrm{~km} / \mathrm{s}$ in the uppermost part to $6.4 \mathrm{~km} / \mathrm{s}$ in the deeper part, with a mean value close to $6.1 \mathrm{~km} / \mathrm{s}$. The second phase must be modeled as a reflection at an intracrustal discontinuity (PcP), located at about $20 \mathrm{~km}$ depth and well-constrained in two segments of the profile (black lines in Fig. 7a). Although the control on the velocity of the lower layer is scarce, values typically corresponding to lower crust $(6.7-6.9 \mathrm{~km} / \mathrm{s})$ are consistent with the observations. Regarding the Moho topography, no constraints are provided by this record section. As shown in Fig. 7a (bottom panel), the location of the proposed mid-crust reflector is coincident with the convertors observed in the central section of the RF transect at depths ranging between 15 and $20 \mathrm{~km}$. The RF-derived Moho is consistent with the geometry inferred from the late 70s wide-angle reflection/refraction profiles running west-to-east along the northern and southern sides of the chain (Gallart et al., 1981; Daignières et al., 1981), shown as blue segments at Fig. 7a (lower panel). It is worthy to note that using data from the same experiment,

b)
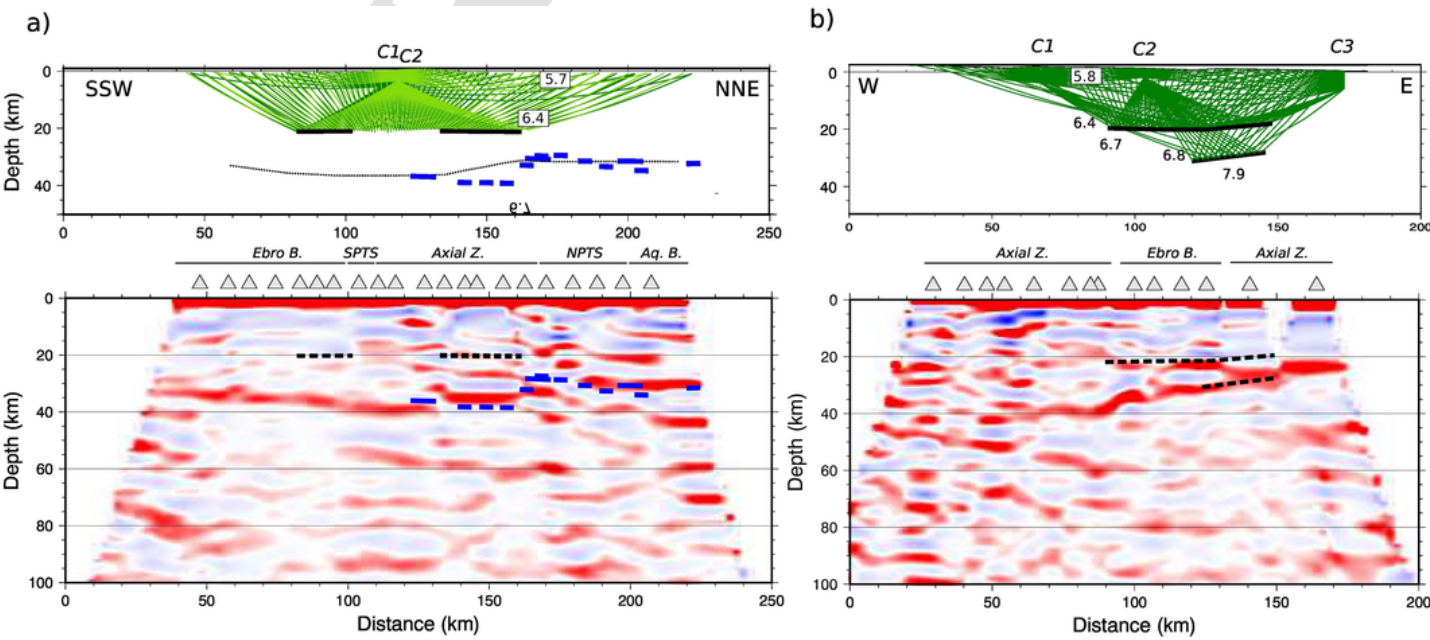

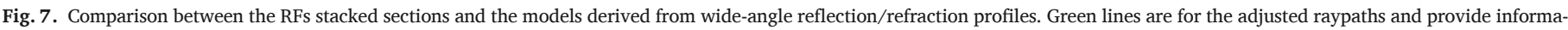

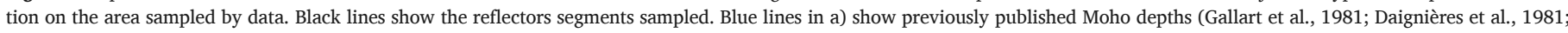

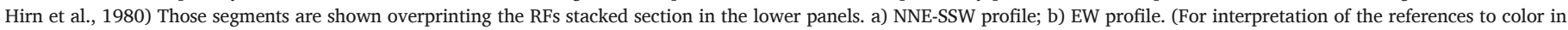
this figure legend, the reader is referred to the web version of this article.) 
Hirn et al. (1980) recorded a controlled source fan profile sampling a zone close to the Pyrope N-S transect. Their results show clear north-south variations in crustal thickness, with a Moho around $40 \mathrm{~km}$ beneath the Axial Zone, a $10 \mathrm{~km}$ shift beneath the NPF and a northward deepening along the NPTS, from $28 \mathrm{~km}$ near the NPF to $34 \mathrm{~km}$ northwards and raising again to reach $30 \mathrm{~km}$ at the northern end of the line. Although not fully consistent with the new data, both datasets coherently show a patched geometry for the Moho discontinuity beneath the eastern termination of the Pyrenees.

\section{- E-W profile}

Event C1 is located near station CPAL, at the eastern edge of the profile. This has allowed to record the signal at offsets up to $140 \mathrm{~km}$, better sampling the whole crust. Three different phases, tentatively interpreted as $\mathrm{Pg}, \mathrm{PcP}$ and $\mathrm{PmP}$, have been identified in the record sections (Fig. 6b). In order to account for these observations, we have used a three-layered model, with upper and lower crusts separated by a velocity discontinuity and overlying a homogeneous mantle (Fig. 7b). The geometry of the Moho in the initial model has been derived from RFs results and hence includes a gentle shallowing to the east. The Pg phases refracted within the upper crust have been modeled with a velocity gradient increasing from $5.8 \mathrm{~km} / \mathrm{s}$ near the surface to $6.4 \mathrm{~km} / \mathrm{s}$ at the base of the layer. In order to match the arrivals from the three events in a consistent model, the mid-crustal discontinuity must include some lateral depth variations; beneath the eastern part of the area effectively sampled by the data (black lines in the lower panel of Fig. 7b), the discontinuity is located at $17 \mathrm{~km}$, while beneath the central segment of the transect, its depth reaches $20 \mathrm{~km}$. The velocity of the lower crust is here better constrained than in the previous case, as PcP and PmP phases are available. A value of $6.7-6.8 \mathrm{~km} / \mathrm{s}$ is retained in the final model (Fig. 7b). The observed PmP time arrivals are consistent with the theoretical ones calculated using the Moho topography derived from RFs, with a crustal thickness of $26-27 \mathrm{~km}$ near the east of the line to $30-32 \mathrm{~km}$ beneath station FP27.

\section{- Fan profile}

The recording geometry of the 29/10/2015 Gulf of Roses event provides a large number of records at very similar distances $(74-86 \mathrm{~km})$ sampling different azimuths. The E-W record section discussed above shows that at distances around $80 \mathrm{~km}$, the first arrival is a PcP phase, followed $0.5 \mathrm{~s}$ later by the more energetic PmP arrivals. Assuming that reflections do occur at the mid-point between source and receiver, this fan profile is expected to investigate a limited area located south of station CBEU, close to the limit between the Axial and southern Pyrenees zones (Fig. 6c).

This fan profile evidences a large time jump of $0.4 \mathrm{~s}$ between the PmP arrivals at stations FP08 and FP09, reaching $0.8 \mathrm{~s}$ for stations located further north. Assuming an homogeneous crust with a $6.3 \mathrm{~km} / \mathrm{s}$ mean velocity, a difference around $3 \mathrm{~km}$ in crustal depth at the location where rays are reflected (assumed to be the geometric midpoint) is required to explain this $0.4 \mathrm{~s}$ lag. Hereof, between the reflection zone, located near station CBEU, the limit between Iberian and Eurasian crust is still marked by a crustal thickness variation of close to $3 \mathrm{~km}$, clearly smaller than those observed further west by Hirn et al. (1980) and consistent with the image of a segmented Moho deduced from the NNE-SSW RF stacked section. Therefore, this fan profile allows us to extend eastwards the area imaged seismically and prove that at longitudes around $2.8^{\circ} \mathrm{E}$, close to the location of the Canigó Massif, the transition between the Iberian and European crusts still shows a certain degree of complexity, including minor, but not negligible changes in crustal depth.

\section{Discussion}

The eastern Pyrenees compressive structure along the NNE-SSW profile is well documented in several balanced and restored cross-sections that show a complete preservation of the main tectonic domains (Grool et al., 2018; Vergés et al., 1995). These are, from north to south: the Aquitaine basin, the North Pyrenean thrust system, the Axial Zone, the South Pyrenean thrust system and the Ebro foreland basin. The NNE-SSW profile is located close to the west of the area dominated by extensional faults where the crust begins to thin eastwards. This is corroborated by the results of the E-W profile, which shows a gentle thinning towards the east that becomes stronger east of FP25 station (Fig. 5), and by the tectonic map, which shows a large normal fault system involving the NE corner of Iberia and the adjacent regions of SE France (e.g., Lewis et al., 2000; Vergés and Fernàndez, 2006) (Fig. 1). The relatively thick crust along the entire profile, the north-dipping geometry of the Iberian Moho and the location of its two short northern segments underneath the European Moho suggest a preserved compressive geometry. However, we cannot be conclusive on this point as the profile crosses obliquely through the main regional Oligocene-Miocene extensive structure, the Têt Fault limiting the La Seu, the La Cerdanya, the Conflent and the Perpinyà basins. Yet, if the observed structure of the crust still represents the preserved compressive structure as in the central and western profiles (Chevrot et al., 2015, 2018), the discontinuity of the Moho segments, their apparent imbrication and the lack of a large underthrusting of Iberia below Europe suppose a challenging problem to solve. In the following, the existing geological information available for the eastern Pyrenees is integrated with the observed geometry of the Moho to propose a model to interpret this conundrum.

The eastern Pyrenees, according to plate tectonic models, show the greatest separation of about $135 \mathrm{~km}$ between Iberia and Europe decreasing progressively towards the west just before the onset of the convergence at $83.5 \mathrm{Ma}$ (Macchiavelli et al., 2017). The maximum crustal shortening amounts have been estimated at $75-80 \mathrm{~km}$ for the western segment of the orogen (Teixell et al., 1998) and $95-150 \mathrm{~km}$ in the central Pyrenees (Mouthereau et al., 2014; Muñoz, 1992). To the East, where a larger shortening should be expected, the available geological information has allowed to justify only $111-125 \mathrm{~km}$ of shortening (Vergés et al., 1995; Grool et al., 2018). These apparent mismatches between the values of continental separation and shortening, as well as the partitioned Moho structure along the eastern profile, could be resolved by the existence of strips of Aptian-Albian exhumed upper mantle. Numerous multidisciplinary studies integrating tectonics, thermal metamorphism, sedimentation, thermochronology, and numerical modeling have documented the existence of an hyperextended domain in the central and western part of the Pyrenees (e.g., Brune et al., 2017; Pérez-Gussinyé, 2013; Jammes et al., 2009; Clerc and Lagabrielle, 2014; Lagabrielle et al., 2010) likewise along the western margin of Iberia (e.g., Pérez-Gussinyé, 2013). These strips of exhumed mantle are constrained by an almost continuous belt of thermal metamorphism affecting Cretaceous sedimentary successions and by the abundant outcrops of lherzolites. However, the discontinuous and small size outcrops of these upper mantle rocks make difficult to reconstruct the original width of the mantle exhumed domains. Recent balanced and restored cross-sections across the Pyrenees include mantle exhumed domains between Iberia and Europe before the onset of convergence (e.g., de Saint Blanquat et al., 2016; Grool et al., 2018; Masini et al., 2014; Mouthereau et al., 2014; Teixell et al., 2018; Tugend et al., 2014).

Comparing the eastern part of the Pyrenees with the central and western parts of the range, we can note that the distance between margins at the onset of the convergence was larger in the east, the estimated values of shortening are similar or even lower in the east and 
that the present-day structure of the Moho in the Eastern Pyrenees is segmented, slightly dipping to the north, and does not show evidences of significant overthrusting of the European crust above the Iberia, unlike the central and western Pyrenees. The new concepts on highly extended margins including exhumed mantle domains provide a good explanation for the short and multiple Mohos segments observed beneath the Eastern Pyrenees. Although the tectonic behavior of exhumed mantle during compression is difficult to preserve in the fossil record, it may have worked as in the southern margin of the Bay of Biscay, where the Iberian hyperextended crust overthrusted to the north the highly serpentinized exhumed mantle tectonic domain (e.g., Tugend et al., 2014).

The pre-shortening configuration proposed to match the dissimilar crustal scale structure observed in the NNE-SSW profile for the eastern Pyrenees is based on the work by Clerc et al. (2015). Their geological model includes two deep basins basins separating the Iberian and European margins from a central continental block corresponding to the North Pyrenean massif. The two basins show HT/LP metamorphism and would be floored by either a thin crust or directly by upper mantle rocks. The collision between the Iberian plate, the North Pyrenean massif block and the European plate, each with a different Moho, could reproduce the segmented Mohos observed in the NNE-SSW profile, assuming that the thin crust and the upper mantle would have been mostly consumed by underthrusting during the convergence. It is important, however, to be aware that there is a significant decoupling between the outcropping structures defined by Clerc et al. (2015), that were tectonically transported to the north in the hangingwall of the north Pyrenean thrust system, and the position of the different segments of the Moho as imaged in the NNE-SSW seismic profile. Despite these shortcomings, we propose a configuration of the margins of the eastern Pyrenees characterized by one or two large and thick continental blocks separating narrow and deep basins floored by very thin continental crust or exhumed mantle rocks. The different basement massifs outcropping along the northern side of the eastern Pyrenees would be consistent with this model.

Crustal thinning observed in E-W Profile clearly shows the overprint of the Neogene extension in the NE corner of Iberia (Fig. 1). This crustal thinning occurred by the combination of surficial erosion linked to the uplift of the footwall of the Transverse Fault system and by stretching of the crust at depth. Two large areas of NE Iberia show $1.2-2.0 \mathrm{~km}$ of footwall related uplift linked to the Oligocene-early Miocene activity of the Catalan Coastal Fault system and to the late Miocene-Quaternary extension of the Transverse Fault system as determined by Lewis et al. (2000). The Amer-Brugent fault has a tectonic displacement of $1.0-1.4 \mathrm{~km}$ and its footwall shows a preserved flexural topography that extends about $15 \mathrm{~km}$ to the west of the fault scarp (Saula et al., 1994). The geological map of this region also shows westward bedding dips of Eocene foreland basin deposits for tens of km away from the Transverse Fault system indicating the large-scale uplift and exhumation of its footwall (ICC, 1989). In addition to the surficial erosion, the E-W Profile shows a seemingly progressive thinning of the crust in depth and does not seem visibly affected by the Transverse Fault system (Fig. 5). We propose that observed crustal thinning could result from the progressive thinning and pinch out of the lower crust under the Transverse Fault system east of FP28 station.

\section{Conclusions}

The new data and methodological approaches used in this contribution have allowed to show the complex crustal structure along the NNE-SSW profile crossing the eastern part of the Pyrenees, including a gently north-dipping Moho beneath the Iberia foreland and a subhorizontal and slightly thinner Eurasian crust. Beneath the Axial Zone, the Moho is divided into segments dipping northwards and showing a step- wise geometry. This configuration is clearly different from the image obtained previously further west, where the Iberian Moho shows a continuous north-dipping attitude and its northern edge is clearly located beneath the European Moho. The integration of surficial geology and Moho structure at depth seems to indicate that the compressive structures are still preserved along the NNE-SSW profile, which is not or only slightly affected by Neogene extension. The Têt Fault cuts the upper crust but there are no evidence suggesting that this fault affects the deeper crustal regions.

The E-W profile shows a significant crustal thinning from $45 \mathrm{~km}$ in the west, beneath the Axial Zone, to $22 \mathrm{~km}$ in the east, already in the Neogene Empordà Basin. The observed crustal thinning is related to the Oligocene-Miocene western Mediterranean evolution and occurred by the combination of Neogene crustal thinning, at the level of the lower crust, and $>2.5 \mathrm{~km}$ of regional westwards tilt and exhumation in the footwall of the Transverse Fault system.

Wide-angle reflection/refraction profiles built using natural seismicity events are consistent with the results derived from RFs analysis, hence providing an independent confirmation of those results. The most prominent phase along the NNE-SSW profile corresponds to a mid-crust reflector located near $20 \mathrm{~km}$ depth. The E-W profile allows to identify a mid-crust reflector near $20 \mathrm{~km}$ and also reflections at the base of the crust, consistent with the crustal thickness estimations from RFs results. The interpretation of the results from a fan profile shows that at longitudes around $2.8^{\circ} \mathrm{E}$, close to the Canigó Massif, a significant jump in the Moho depth can still be observed. This area, showing significant changes in topography, gravity and seismic tomography, can hence be considered as a major limit between a western domain, dominated by crustal imbrication and an eastern domain, where the Neogene extensional overprint is greater.

In order to explain the observed crustal geometry variations, we propose a model in which the observed segmented Moho structure beneath the eastern Pyrenees is interpreted as the result of a different Mesozoic pre-shortening margin architecture, configured by two small continental blocks, located between Iberia and Europe, and bounded by two basins with extremely thin crust or floored by exhumed mantle. Under this hypothesis, the convergence would have been accommodated by the consumption of the previously thinned crust or exhumed mantle and stopped when the continental blocks collided directly.

Supplementary data to this article can be found online at https:// doi.org/10.1016/j.tecto.2018.07.011.

\section{Acknowledgments}

This work was funded by the Spanish Ministry of Economy and Competitiveness Project MISTERIOS (CGL2013-48601-C2-2-R), with additional support from the Generalitat de Catalunya grant 2017SGR1022 and projects ALPIMED (PIE-CSIC-201530E082) and SUBTETIS (PIE-CSIC-201830E039). The PYROPE experiment was supported by the French Research Agency ANR blanc programme (project PYROPE, ANR-09-BLAN-0229).

Seismic data form the temporary seismic deployment can be obtained from the RESIF EIDA node (http://portal.resif.fr/). Data from permanent stations can also be recovered using the EIDA services. We acknowledge the French RESIF network (https://doi.org/10.15778/ RESIF.FR), the Spanish Digital Seismic Network and the Catalan Seismic Network (https://doi.org/10.7914/SN/CA) for providing access to their data.

\section{References}

Ammon, C.J., 1997. An Overview of Receiver Function Analysis. In: http://eqseis.geosc. psu.edu/ cammon/HTML/RftnDocs/rftn01.html.

Anadón, P., Cabrera, Ll., Guimerà, J., Santanach, P.F., 1985. Paleogene strike-slip deformation and sedimentation along the southeastern margin of the Ebro Basin. In: Bid- 
dle, K., Christie Blick, E. (Eds.), Strike Slip Deformation, Basin Formation and Sedimentation. Special Publication of the Soc. Ec. Pal. and Min 37, pp. 303-318.

Arthaud, F., Matte, P., 1975. Les décrochements tardi-hercyniens du Sud-Ouest de l'Europe. Géometrie et essai de reconstitution des conditions de la déformation. Tectonophysics 25, https://doi.org/10.1016/0040-1951(75)90014-1.

Asensio, E., Khazaradze, G., Echeverria, a., King, R.W., Vilajosana, I., 2012. GPS studies of active deformation in the Pyrenees. Geophys. J. Int. 190, 913-921. https://doi.org/ 10.1111/j.1365-246X.2012.05525.x.

Ayala, C., Bohoyo, F., Maestro, A., Reguera, M.I., Torne, M., Rubio, F., Fernàndez, M., García-Lobón, J.L., 2016. Updated Bouguer anomalies of the Iberian Peninsula: a new perspective to interpret the regional geology. J. Maps https://doi.org/10.1080/ 17445647.2015.1126538.

Bolós, X., Martí, J., Becerril, L., Planagumà, L., Grosse, P., Barde-Cabusson, S., 2015. Volcano-structural analysis of La Garrotxa Volcanic Field (NE Iberia): implications for the plumbing system. Tectonophysics 642, 58-70. https://doi.org/10.1016/j.tecto.2014. 12.013.

Brune, S., Corti, G., Ranalli, G., 2017. Controls of inherited lithospheric heterogeneity on rift linkage: numerical and analog models of interaction between the Kenyan and Ethiopian rifts across the Turkana depression. Tectonics 36, 1767-1786. https://doi. org/10.1002/2017TC004739.

Cabal, J., Fernàndez, M., 1995. Heat flow and regional uplift at the north-eastern border of the Ebro basin, NE Spain. Geophys. J. Int. 121, 393-403.

Capote, R., Muñoz, J.A.J.A., Simón, J.L., Liesa, C.L., Arlegui, L.E., Simón, J.L., Arlegui, 2002. Alpine tectonics I: the Alpine system north of the Betic Cordillera. In: Gibbons, W. Moreno, T. Geol. Spain. Geol. Soc. London. pp. 367-400.

Casas, A., Kearey, P., River, L., Adam, C.R., 1997. Gravity Anomaly Map of the Pyrenean Region and a Comparison of the Deep Geological Structure of the Western and Eastern Pyrenees. 150, 65-78.

Chevrot, S., Van Der Hilst, R.D., 2000. The Poisson ratio of the Australian crust: geological and geophysical implications. Earth Planet. Sci. Lett. 183, 121-132. https://doi.org/ 10.1016/S0012-821X(00)00264-8.

Chevrot, S., Sylvander, M., Delouis, B., 2011. Tectonophysics a preliminary catalog of moment tensors for the Pyrenees. Tectonophysics 510, 239-251. https://doi.org/10. 1016/j.tecto.2011.07.011.

Chevrot, S., Villasenor, A., Sylvander, M., Benahmed, S., Beucler, E., Cougoulat, G., Delmas, P., Blanquat, M.D.S., Diaz, J., Gallart, J., Grimaud, F., Lagabrielle, Y., Manatschal, G., Mocquet, A., Pauchet, H., Paul, A., Péquegnat, C., Quillard, O., Roussel, S., Ruiz, M., Wolyniec, D., 2014. High-resolution imaging of the Pyrenees and massif central from the data of the PYROPE and IBERARRAY portable array deployments. J. Geophys. Res. B: Solid Earth https://doi.org/10.1002/2014JB010953.

Chevrot, S., Sylvander, M., Diaz, J., Ruiz, M., Paul, A., Cougoulat, G., Péquegnat, C., Wolyniec, D., Delmas, P., Grimaud, F., Benahmed, S., Pauchet, H., de Saint Blanquat, M., Lagabrielle, Y., Manatschal, G., 2015. The Pyrenean architecture as revealed by teleseismic P-to-S converted waves recorded along two dense transects. Geophys. J. Int. https://doi.org/10.1093/gji/ggu400.

Chevrot, S., Sylvander, M., Diaz, J., Martin, R., Mouthereau, F., Manatschal, G., Masini, E., Calassou, S., Grimaud, F., Pauchet, H., Ruiz, M., 2018. The non-cylindrical crustal architecture of the Pyrenees. Sci. Rep.(accepted, in press).

Choukroune, P., ECORS Team, 1989. The ECORS Pyrenean deep seismic profile reflection data and the overall structure of an orogenic belt. Tectonics $8,23-39$. https://doi.org/ 10.1029/TC008i001p00023.

Choukroune, P., Mattauer, M., 1978. Tectonique des plaques et Pyrénées: sur le fonctionnement de la faille transformante nord-Pyrénéenne; comparaisons avec des modèles actuels. Bull. Soc. Geol. Fr. 7, 689-700, (t. XX).

Clerc, C., Lagabrielle, Y., 2014. Thermal control on the modes of crustal thinning leading to mantle exhumation: insights from the Cretaceous Pyrenean hot paleomargins. Tectonics 33, 1340-1359. https://doi.org/10.1002/2013TC003471.

Clerc, C., Lahfid, A., Monié, P., Lagabrielle, Y., Chopin, C., Poujol, M., Boulvais, P., Ringenbach, J.-C., Masini, E., de Saint Blanquat, M., 2015. High-temperature metamorphism during extreme thinning of the continental crust: a reappraisal of the North Pyrenean passive paleomargin. Solid Earth 6, 643-668. https://doi.org/10.5194/ se-6-643-2015.

Daignières, M., Gallart, J., Banda, E., 1981. Lateral variation of the crust in the North Pyrenean Zone. Ann. Geophys. 37 (3), 435-456.

Díaz, J., Pedreira, D., Ruiz, M., Pulgar, J.A., Gallart, J., 2012. Mapping the indentation between the Iberian and Eurasian plates beneath the Western Pyrenees/Eastern Cantabrian Mountains from receiver function analysis. Tectonophysics https://doi. org/10.1016/j.tecto.2012.07.005

Diaz, J., Gallart, J., Carbonell, R., 2016. Moho topography beneath the Iberian-western Mediterranean region mapped from controlled-source and natural seismicity surveys. Tectonophysics 692, 74-85. https://doi.org/10.1016/j.tecto.2016.08.023.

Ford, M., Hemmer, L., Vacherat, A., Gallagher, K., Christophoul, F., 2016. Retro-wedge foreland basin evolution along the ECORS line, eastern Pyrenees, France. J. Geol. Soc. Lond. 2015-129, https://doi.org/10.1144/jgs2015-129.

Gallart, J., Daignières, M., Banda, E., Suriñach, E., Hirn, A., 1980. The eastern Pyrenean domain: lateral variations at crust-mantle level. Ann. Geophys. 36 (2), 141-158.

Gallart, J., Banda, E., Daignières, M., 1981. Crustal structure of the Paleozoic Axial Zone of the Pyrenees and transition to the North Pyrenean Zone. Ann. Geophys. 37 (3), $457-480$.

Gallart, J., Díaz, J., Nercessian, A., Mauffret, A., Dos Reis, T., 2001. The eastern end of the Pyrenees: seismic features at the transition to the NW Mediterranean. Geophys. Res. Lett. 28 (11), 2277-2280.

Giménez, J., Suriñach, E., Fleta, J., Goula, X., 1996. Recent vertical movements from high-precision leveling data in northeast Spain. Tectonophysics 263, 149-161. https: //doi.org/10.1016/S0040-1951(96)00037-6.

Grool, A.R., Ford, M., Vergés, J., Huismans, R.S., Christophoul, F., Dielforder, A., 2018. Insights into the crustal-scale dynamics of a doubly vergent orogen from a quantitative analysis of its forelands: a case study of the eastern Pyrenees. Tectonics https://doi. org/10.1002/2017TC004731.
Gueguen, E., Doglioni, C., Fernandez, M., 1998. On the post-25 Ma geodynamic 592 evolution of the western Mediterranean. Tectonophysics 298, 259-269.

Guimerà, J., 1984. Palaeogene evolution of deformation in the northeastern Iberian Penin sula. Geol. Mag. 121, 413-420.

Hirn, A., Daignières, m., Gallart, J., Vadell, M., 1980. Explosion seismic sounding of throws and dips in the continental Moho. Geophys. Res. Lett. 7 (4), 263-266.

Institut Cartogràfic i Geològic de Catalunya, 1989. Mapa geològic de Catalunya, Scale 1:250.000. Inst. Cart. Catalunya, Barcelona, Spain.

Institut Cartogràfic i Geològic de Catalunya, 2000. Catalan Seismic Network. International Federation of Digital Seismograph Networks. Other/Seismic Network. https:// doi.org/10.7914/SN/CA.

Instituto Geográfico Nacional, 1999. Spanish Digital Seismic Network.

Jammes, S., Manatschal, G., Lavier, L., Masini, E., 2009. Tectonosedimentary evolution related to extreme crustal thinning ahead of a propagating ocean: example of the western Pyrenees. Tectonics 28, TC4012https://doi.org/10.1029/2008tc002406.

Jammes, S., Huismans, R.S., Muñoz, J.A., 2014. Lateral variation in structural style of mountain building: controls of rheological and rift inheritance. Terra Nova 26, 201-207. https://doi.org/10.1111/ter.12087.

Jammes, S., Persaud, P., Lavier, L., Manatschal, G., 2014. Correction to "extreme crusta thinning in the Bay of Biscay and the Western Pyrenees: from observations to modeling”. Geochem. Geophys. Geosyst. 15, 830-832. https://doi.org/10.1002/ 2013GC005051.

Jones, C.H., Phinney, R.A., 1998. Seismic structure of the lithosphere form teleseismic converted arrivals observed at small arrays in the southern Sierra Nevada and vicinity, California. J. Geophys. Res. 103 (B5), 10,065-10,090.

Kennett, B.L.N., Engdahl, E.R., Buland, R., 1995. Constraints on seismic velocities in the Earth from traveltimes. Geophys. J. Int. 122, 108-124.

Lagabrielle, Y., Labaume, P., de Saint Blanquat, M., 2010. Mantle exhumation, crustal denudation, and gravity tectonics during Cretaceous rifting in the Pyrenean realm (SW Europe): insights from the geological setting of the lherzolite bodies. Tectonics 29 , TC4012https://doi.org/10.1029/2009TC002588.

Langston, C.A., 1979. Structure under Mount Rainier, Washington, inferred from teleseismic body waves. J. Geophys. Res. 84, 4749-4762.

Lewis, C.J., Vergés, J., Marzo, M., 2000. High mountains in a zone of extended crust insights into the Neogene-Quaternary topographic development of northeastern Iberia. Tectonics 19, 86-102. https://doi.org/10.1029/1999tc900056.

Lombardi, D., Braunmiller, J., Kissling, E., Giardini, D., 2008. Moho Depth and Poisson's Ratio in the Western - Central Alps From Receiver Functions. 249-264. https://doi. org/10.1111/j.1365-246X.2007.03706.x.

Macchiavelli, C., Vergés, J., Schettino, A., Fernàndez, M., Turco, E., Casciello, E., Torne, M., Pierantoni, P.P., Tunini, L., 2017. A new Southern North Atlantic Isochron Map: insights into the drift of the Iberian Plate since the Late Cretaceous. J. Geophys. Res. Solid Earth https://doi.org/10.1002/2017JB014769.

Mancilla, F.L., Diaz, J., 2015. High resolution Moho topography map beneath Iberia and Northern Morocco from receiver function analysis. Tectonophysics https://doi.org/ 10.1016/j.tecto.2015.06.017.

Martí, J., Mitjavila, J., Roca, E., Aparicio, A., 1992. Cenozoic magmatism of the Valencia trough (western Mediterranean): relationship between structural evolution and volcanism*. Tectonophysics 203, 145-165. https://doi.org/10.1016/ 0040-1951(92)90221-Q

Mattauer, M., 1990. Une autre interpretation du profil ECORS Pyrenees. Bull. Soc. Geol. Fr. VI, 307-311. https://doi.org/10.2113/gssgfbull.vi.2.307.

Mohsen, A., Hofstetter, R., Bock, G., Kind, R., Weber, M., Wylegalla, K., Rümpker, G., 2005. A receiver function study across the Dead Sea transform. Geophys. J. Int. 160 (3), 948-960. https://doi.org/10.1111/j.1365-246X.2005.02534.x.

Mouthereau, F., Filleaudeau, P., Vacherat, A., Pik, R., Lacombe, O., Fellin, M.G., Castelltort, S., Christophoul, F., Masini, E., 2014. Placing limits to shortening evolution in the Pyrenees: role of margin architecture and implications for the Iberia/Europe convergence. Tectonics 33, 2283-2314. https://doi.org/10.1002/2014TC003663.

Muñoz, J.A., 1992. In: McClay, K.R. (Ed.), Evolution of a Continental Collision Belt: ECORS-Pyrenees Crustal Balanced Cross-section. Thrust Tectonics. London Chapman Hall, pp. 235-246. https://doi.org/10.1007/978-94-011-3066-0_21.

Nair, S.K., Gao, S.S., Liu, K.H., Silver, P.G., 2006. Southern African crustal evolution and composition: constraints from receiver function studies. J. Geophys. Res. 111 (B2), 1-17. https://doi.org/10.1029/2005JB003802.

Nguyen, H.N., Vernant, P., Mazzotti, S., Khazaradze, G., Asensio, E., 2016. 3-D GPS velocity field and its implications on the present-day post-orogenic deformation of the Western Alps and Pyrenees. Solid Earth 7, 1349-1363. https://doi.org/10.5194/ se-7-1349-2016.

Olivet, J.L., 1996. Kinematics of the Iberian plate. Bull. Centres Rech. Explor. Prod. Elf-Aquitaine 20, 131-195.

Palomeras, I., Villaseñor, A., Thurner, S., Levander, A., Gallart, J., Harnafi, M., 2017. Lithospheric structure of Iberia and Morocco using finite-frequency Rayleigh wave tomography from earthquakes and seismic ambient noise. Geochem. Geophys. Geosyst. 18, 1824-1840. https://doi.org/10.1002/2016GC006657.

Pérez-Gussinyé, M., 2013. A tectonic model for hyperextension at magma-poor rifted margins: an example from the West Iberia-Newfoundland conjugate margins. Geol. Soc Lond., Spec. Publ. 369 (1), 403-427.

Puigdefàbregas, C., Souquet, P., 1986. Tecto-sedimentary cycles and depositional sequences of the Mesozoic and Tertiary from the Pyrenees. Tectonophysics 129, 173-203. https://doi.org/10.1016/0040-1951(86)90251-9.

Pujadas, J., Casas, J.M., Muñoz, J.A., Sàbat, F., 1989. Thrust tectonics and Paleogene syntectonic sedimentation in the Emporda area, southeastern Pyrenees. Geodin. Acta 3, 195-206.

RESIF, 1995. RESIF-RLBP French Broad-band network, RESIF-RAP strong motion network and other seismic stations in metropolitan France. In: RESIF - Réseau Sismologique et géodésique Français. Seismic Network. https://doi.org/10.15778/RESIF.FR.

Rigo, A., Vernant, P., Feigl, K.L., Goula, X., Khazaradze, G., Talaya, J., Morel, L., Nicolas, J., Baize, S., Chéry, J., Sylvander, M., 2015. Present-day deformation of the pyrenee 
revealed by GPS surveying and earthquake focal mechanisms until 2011. Geophys. J. Int. 201, 947-964. https://doi.org/10.1093/gji/ggv052.

Rivero, L., Pinto, V., Casas, A., 2002. Moho depth structure of the eastern part of the Pyrenean belt derived from gravity data. J. Geodyn. 33, 315-332.

Roure, F., Choukroune, P., Berastegui, X., Muñoz, J.A., Villien, A., Matheron, P., Bareyt, M., Séguret, M., Camara, P., Déramond, J., 1989. Ecors deep seismic data and balanced cross sections: geometric constraints on the evolution of the Pyrenees. Tectonics 8, 41-50. https://doi.org/10.1029/TC008i001p00041.

Saula, E., Picart, J., Mató, E., Llenas, M., Losantos, M., Berástegui, X., Agustí, J., 1994. Evolución geodinámica de la fosa del Empordà y las Sierras Transversales. Acta Geol. Hisp. 29, 55-75.

Sheriff, R.E., Geldart, L.P., 1982. Exploration Seismology Volume I: History, Theory and Data Aquisition. Cambridge University Press, Cambridge.

Teixell, A., 1998. Crustal structure and orogenic material budget in the west central Pyrenees. Tectonics 17, 395-406. https://doi.org/10.1029/98tc00561.

Teixell, A., Labaume, P., Lagabrielle, Y., 2016. The crustal evolution of the west-central Pyrenees revisited: inferences from a new kinematic scenario. Compt. Rendus Geosci. 348, 257-267. https://doi.org/10.1016/j.crte.2015.10.010.

Teixell, A., Labaume, P., Ayarza, P., Espurt, N., de Saint Blanquat, M., Lagabrielle, Y., 2018. Crustal structure and evolution of the Pyrenean-Cantabrian belt: a review and new interpretations from recent concepts and data. Tectonophysics https://doi.org/ 10.1016/j.tecto.2018.01.009.

Torne, M., Fernàndez, M., Vergés, J., Ayala, C., Salas, M.C., Jimenez-Munt, I., Buffett, G.G., Díaz, J., 2015. Crust and mantle lithospheric structure of the Iberian Peninsula deduced from potential field modeling and thermal analysis. Tectonophysics 663, 419-433. https://doi.org/10.1016/j.tecto.2015.06.003.

Tugend, J., Manatschal, G., Kusznir, N.J., Masini, E., Mohn, G., Thinon, I., 2014. Formation and deformation of hyperextended rift systems: insights from rift domain map- ping in the Bay of Biscay-Pyrenees. Tectonics 33, 1239-1276. https://doi.org/10.1002/ 2014 tc003529.

Vergés, J., 1993. Estudi geològic del vessant sud del Pirineu oriental i central. Evolució cinemàtica en 3D (PhD Thesis). Univ. Barcelona, 1-199.

Vergés, J., Fernàndez, M., 2006. Ranges and basins in the Iberian Peninsula: their contribution to the present topography. Geol. Soc. Lond. Mem. 32, 223-234. https://doi. org/10.1144/GSL.MEM.2006.032.01.13.

Vergés, J., Millán, H., Roca, E., Muñoz, J.A., Marzo, M., Cires, J., Bezemer, T., Zoetemeijer, R., Cloetingh, S., Puigdefabregas, C., 1995. Eastern Pyrenees and related foreland basins: pre-, syn- and post-collisional crustal-scale cross-sections. Mar. Pet. Geol. 12, 903-915. https://doi.org/10.1016/0264-8172(95)98854-X.

Vergés, J., Fernàndez, M., Martínez, A., 2002. The Pyrenean orogen: pre-, syn-, and post-collisional evolution. J. Virtual Explor. 8, 55-74. https://doi.org/10.3809/ jvirtex.2002.00058.

Vinnik, L.P., 1977. Detection of waves converted from P to SV in the mantle. Phys. Earth Planet. Inter. 15, 39-45.

Wang, Y., Chevrot, S., Monteiller, V., Komatitsch, D., Mouthereau, F., Manatschal, G., Sylvander, M., Diaz, J., Ruiz, M., Grimaud, F., Benahmed, S., Pauchet, H., Martin, R. 2016. The deep roots of the western Pyrenees revealed by full waveform inversion of teleseismic P waves. Geology https://doi.org/10.1130/G37812.1.

Zelt, C.A., Smith, R.B., 1992. Seismic traveltime inversion for 2-D crustal velocity structure. Geophys. J. Int. 108, 16-34.

Zhu, L., Kanamori, H., 2000. Moho depth variation in southern California from teleseismic receiver functions. J. Geophys. Res. 105, 2969-2980. https://doi.org/10.1029/ 1999JB900322. 
The NNE-SSW profile has a length of $180 \mathrm{~km}$ and is imaged using waves from events $\mathrm{C} 1$ and $\mathrm{C} 2$, both located in its central sector. These two events are not fully aligned along the profile but lay $17 \mathrm{~km}$ west and $12 \mathrm{~km}$ east respectively. Event C2 shows direct waves at offsets up to $100 \mathrm{~km}$, both in the south and north directions (Fig. 6a). These phases, interpreted as being refracted within the basement and labeled Pg, propagate with apparent velocities of $5.5-6.0 \mathrm{~km} / \mathrm{s}$ and $6.0 \mathrm{~km} / \mathrm{s}$ to the south and north respectively. A weak secondary phase arriving later has been identified at offsets of $55-90 \mathrm{~km}$ to the north. This phase can be interpreted as the wide-angle reflection at the top of the lower crust (PcP) or, alternatively, as a reflection at the base of the crust (PmP). Event C1 (Supplementary Fig. S1) provide similar features, with PcP/PmP arrivals in the $75-90 \mathrm{~km}$ range to the north (Fig. 6a) which are not observed along the southern sector of the profile.

The EW profile, approximately $150 \mathrm{~km}$ long, has been sampled by waves from the three investigated events, which are almost exactly aligned with the profile. Events C1 and C2 are located near the center of the profile, while event C3 lies at the western end of the line, allowing to record signals at large offsets sampling the base of the crust. The record section built from event C1 (Supplementary Fig. S2) allows us to identify the Pg phase at offsets up to $60 \mathrm{~km}$, both in the W and E sectors, with apparent velocity close to $6 \mathrm{~km} / \mathrm{s}$. To the East, a second arrival can be identified in the $50-100 \mathrm{~km}$ offset range and has been tentatively identified as a PcP. Event C2, with lower magnitude, only allows us to identify Pg arrivals at shorter distances (Supplementary Fig. S2). The record section built from event $\mathrm{C} 3$ provides evidences of three distinct phase arrivals (Fig. 6b). Pg waves with apparent velocity close to $6 \mathrm{~km} / \mathrm{s}$ are identified at ranges $-10 /-80 \mathrm{~km}$. Later on, a second arrival with higher apparent velocity is identified between -90 and $-140 \mathrm{~km}$ and interpreted as a PcP phase. Finally, a high energetic later phase has been identified between -60 and $-140 \mathrm{~km}$, interpreted as a wide-angle reflection at the base of the crust, PmP.

The stacked record section along this profile (Fig. 4) shows a Moho differentiated in up to 4 segments. For most of the stations, the crustal depth estimations arising from the $\mathrm{H}-\mathrm{\kappa}$ analysis (white circles in Fig. 4) agree nicely with the stacked record section, with differences within the estimated vertical resolution. The southern edge of the RF stacked section shows a well-defined Moho located at $35 \mathrm{~km}$ depth and gently dipping to the north to reach $37 \mathrm{~km}$ beneath station FP07. The central segment of the transect corresponds at surface to the southern-vergent Axial Zone and the NPTS and shows a higher degree of complexity. The Moho appears here as a segmented reflector; beneath stations CBRU and FP08, the Moho is identified at around $40 \mathrm{~km}$ depth, following the gentle north-dipping observed beneath the southern sector. Further north, the pseudo-migrated image built using high frequency RFs suggests that the Moho is formed by two different segments gently dipping north (stations FP09-FP12 and FP13-FP15 in Fig. 4). These segments, separated by sharp steps, stand $5-7 \mathrm{~km}$ higher than the adjacent segment to the south and are interpreted as smaller continental blocks located between the Iberian and Eurasian plates. As we are using high frequency RFs, we need to confirm that the segmented image of the Moho beneath the Axial Zone do not result from spurious effects of small-scale lateral variations in the shallower velocity structure. In order to do so, we have recalculated RFs using a more conventional $2 \mathrm{~Hz}$ Gaussian filter, as used previously for other PYROPE profiles (Chevrot et al., 2018). The corresponding NNE-SSW stacked profile (Supplementary Fig. S3) provides a more blurred image, but the presence of a couple of discontinuous Moho segments is still clearly visible. Several convertors are identified within the uppermost $20 \mathrm{~km}$ of crust. Their interpretation is problematical due to the lack of consistency between neighboring stations and the possible contribution of reverberations. The northern segment of the profile, from FP15 to FP18, shows the base of the European crust as a subhorizontal convertor located at $30 \mathrm{~km}$ depth, although both the H-K method and the stacked section suggest that its southern end (station FP15) is slightly more superficial. Above and subparallel to the European Moho there is a consistent convertor at about $20 \mathrm{~km}$ depth that, according to previous models from active source seismic profiles, can be interpreted as the top boundary of the lower crust. 